Christian Bjørnskov and Philipp J.H. Schröder

Are Debt Repayment Incentives Undermined by Foreign Aid?

Department of Economics 


\title{
Are Debt Repayment Incentives Undermined by Foreign Aid?
}

\author{
Christian Bjørnskov and Philipp J.H. Schröder ${ }^{*}$ \\ Department of Economics, Aarhus University
}

This version: November 24, 2010

\begin{abstract}
This paper investigates the effects of inflows of foreign aid on the debt repayment behaviour of developing countries. The paper first delineates the overall incentives to committing to timely repayment in a war of attrition-type model. A set of panel estimates including 93 developing countries shows that foreign aid is strongly negatively associated with repayment incentives. The findings pertain to both total debt service and service on publically guaranteed debt. Only countries that tend to vote predominantly with the US in the UN General Assembly are not significantly discouraged from servicing their debt by inflows of foreign aid.
\end{abstract}

Keywords: Foreign aid, external debt, debt service, political economy

JEL Classification: O15

\footnotetext{
* Aarhus School of Business, Aarhus University, Department of Economics, Hermodsvej 22, DK-8230 Åbyhøj, Denmark. E-mail: chbj@asb.dk. We thank two former students of ours, Christina Bjerg and Sara Toft, for many conversations that inspired this paper and for their ideas that we stole. We are also grateful to Andreas Bergh, Andreas Freytag, Nicolas Corona Juarez, Philipp Meinen, Therese Nilsson, Niklas Potrafke and participants at a seminar at Lund University for commenting on earlier versions of the paper. All errors are of course ours.
} 


\section{Introduction}

A large share of the world's poor countries suffers from disproportionate external debt burdens. A long line of celebrities, including Bono, Muhammad Ali, Sir Bob Geldoff and the Pope, have therefore joined in campaigns such as the Jubilee 2000 campaign to call for a cancellation of developing countries' debts, as well as for an increase in foreign aid to these countries. Since the inception of the Jubilee campaign and other similar initiatives about a decade ago, and the launch of the Highly Indebted Poor Countries (HIPC) initiative - as well as even earlier initiatives in the Baker and Brady Plans - developing countries have received debt relief worth more than 50 billion dollars (Freytag and Pehnelt, 2009). The underlying idea of these initiatives is that developing countries have ended up with an excessive debt burden and are now unable to finance growth-promoting and pro-poor policies (Feeny and McGillivray, 2003; Johansson, in press).

Yet, campaigns, celebrities and many social scientists have acted as if governments and politicians in developing countries are always benevolent and trustworthy partners, i.e. that they would almost always engage in pro-poor, growth-promoting policies if they only had the chance. Feeny and McGillivray (2003), for example, attribute the massive debt problems of HIPCs to benevolent politicians having misconceptions of the social benefits of investments financed by foreign loans, and thus that slow debt repayment or sovereign debt default in poor countries is simply bad luck, i.e. a materialisation of the risk associated with any type of government-conducted investments.

One can nevertheless question the implicit assumptions underlying explanations resting on honest errors or bad luck (i.e. risk) on four central grounds. First, half a century of research in public choice and political economy has suggested that the actions of democratically controlled governments in Western Europe and North America are often best explained by self-interest and that those of developing countries lacking solid checks and balances are even more often so (cf. Mueller, 2003; Imbeau, 2009). Moyo (2009), for example, claims that the large inflows of foreign aid to Africa since 
the 1960s have contributed to worsening the economic situation and human development of the continent by empowering self-interested elites. Results in Bjørnskov (2010) likewise seem to indicate that foreign aid in some countries is primarily captured by political elites that may have little incentive to adopt a long-term horizon necessary to repay foreign loans. The same seems to pertain to funds attained in the international financial markets. As Bulow and Rogoff $(1990,40)$ find, the loans of the 1970s and 1980s were generally misspent and "a very large percentage went to finance conspicuously unpromising government investment projects and capital flight”.

Second, if indebtedness was simply the result of a row of unlucky blows and failed government investments, it should not exhibit such systematic patterns. In particular, one should not find that a relatively small group of countries such as Argentina and Nicaragua are persistent bad payees, accounting for a large share of the accumulated world sovereign debt and bad loans. Third, given systematic patterns of risk and the absence of any significant collateral on offer, one has to ask why marketoriented financial institutions in the western world actually lend money to poor countries? Rational market agents in economics and banks in particular, are not generally perceived as entities that can be fooled repeatedly (see Eaton and Fernandez (1995) for a review on literature dealing with points 2 and 3). Fourth, what if, as some aid critics have suggested, the mounting debt problems and shaky loan repayment are partially caused by foreign aid (Kanbur, 2000; Easterly, 2002; Bjerg et al., in press)?

Against this background, we ask why poor countries are able to build up such excessive debt while at the same time displaying a highly unstable repayment track record and if foreign-aid can in any way exacerbate or alleviate this problem. Our starting point is the observation that loan agreements are, at least in principle, voluntary and based on market conditions, thus subject to negotiations between the sovereign government of a poor country and some financial institutions abroad. Developing countries in general seem to have incentives to repay their foreign debts, for the reason that they desire future access to financial services, i.e. fear exclusion from future lending, and also in other areas need to defend their international reputation. 
On the one hand, Amador (2008) shows theoretically that even in the presence of tragedy-of-thecommons-like problems such as Tornell and Lane's (1999) 'voracity effect', the existence of potential future economic gains can ensure that developing countries repay their debt. The reason is that the same countries value the option of borrowing again in the future, which provides enough incentive to overcome coordination problems. On the other hand, inflows of foreign aid may dramatically change incentives. Mayr (2010) formalizes such concerns in a model in which aid inflows in part depend on countries' indebtedness. Given that donors try to alleviate problems associated with debt burdens, she shows the existence of a moral hazard problem, as politicians that are otherwise benevolent on behalf of their own population have an incentive to rationally run budget deficits. Even without voracity effects or problems of high discount rates due to, e.g., political instability, it is therefore rational to under-service international debt so long as donors are sensitive to the problems this may create; i.e. debtors default because it generates aid inflow. Such problems are further exacerbated when politicians cannot be assumed to be entirely benevolent.

In the present paper we explore a different causal link between aid and debt repayment, namely, we model the loan agreement between the developing country government and the international financial sector as a negotiation of self-interested agents, where the presence of foreign aid may affect the negotiation outcome. In particular, we capture the situation as a war of attrition game where both players, the developing country government and an international bank, are potentially benefiting from large scale finance of projects in the developing country, but have to agree on the terms of the financial transaction and in particular the speed and level of repayment. While both players benefit from an agreement materializing, they are opposed as to what the preferred variety of such agreement looks like. The developing country government prefers large-scale loans with lenient repayment requirements, while the foreign creditor prefers a credible commitment to a speedy repayment schedule at market rates. By not acting (no commitment and no loan) both players can delay the negotiations, and the winner is that agent who is the most patient to wait for his favorite outcome. Adding into this an 
outside financing event - the inflow of foreign aid - which alleviates the current status quo for the developing country, the balance in the war of attrition is changed in favor of the developing country government winning; i.e. obtaining a foreign loan at a slow repayment schedule. The reason is not necessarily that aid agencies react to payment problems, as in Mayr (2010), but that previously agreedupon inflows of foreign aid cause a change in the negotiation balance, forcing the international financial institutions to accept a more lenient loan agreement.

The application of the war of attrition is by no means new. This type of game is, in particular, wellknown from analyses of bargaining situations over economic reforms. ${ }^{1}$ In the current paper we apply the modeling framework to a new problem in order to derive testable hypotheses. A number of disclaimers are in place. We do not build our theoretical argument based on any of the traditional sovereign debt models, as those outlined in, e.g., Eaton and Fernandez (1995), but instead focus on specific aspects surrounding a loan negotiation game. Further, we do not (neither in our theoretical nor empirical considerations), deal explicitly with the dynamics of debt. For example, Easterly (2002) notes that heavily indebted countries seem to replicate past behaviour and engage in heavy borrowing after receiving debt relief and thereby in time become heavily indebted again. Moreover, Hepp (2008) and Johansson (in press) show that HIPC countries did not benefit from debt relief (in terms of growth); these issues are set aside in the current analysis.

We acknowledge that former studies have been plagued by the problem that information on debt relief - when, how much and given to whom - is largely missing before the HIPC Initiative. Studies attempting to estimate or otherwise gather information on earlier debt relief have come a long way, but

\footnotetext{
${ }^{1}$ A number of papers have employed similar approaches as a war of attrition setting applied to bargaining situations over economic reforms. Most prominent among these papers is Alesina and Drazen (1991), who in their seminal paper examine delays in fiscal stabilization. Further examples are Perotti (1998), who studies financial sector reform in transition economies, Heinemann (2000), who discusses the strategic effects of creating the EMU, and Brücker et al. (2004) who are concerned with the eastward enlargement of the European Union.
} 
are still relatively small scale (although see Chauvin and Kraay, 2007). In this paper, we sidestep these problems by exploring the potential effects of foreign aid on actual repayment of either total debts or publically guaranteed debts. The question is whether aid undermines debt repayment, measured as the ratio of debt service to GNI in every five-year period since 1970, given the level of foreign debts.

There are a series of alternative explanations to the causes of debt problems in poor countries, such as Dutch Disease and other externalities, moral hazard, reform delay, incentive distortions, etc. For these and other explanations found in the literature see for example work as early as Friedman (1958) or more recently Corden (1984), Rajan and Subramanian (2008, in press), Bjerg et al. (in press) on Dutch Disease; Doucouliagos and Paldam (2008) on the ineffectiveness of foreign aid to trigger follow-on investments; on government consumption increases or questionable government purchases see the works by Boone (1996), Remmer (2004), Collier and Hoeffler (2007) and on reform delay see Knack (2001, 2004). Hence, this sizable and diverse literature by itself would suggest that foreign aid would cause an increase in poor countries' debt burdens, which may provide part of the explanation for the absence of positive growth effects of aid (cf. Easterly et al., 2004; Paldam and Jensen, 2006; Rajan and Subramanian, 2008). However, a direct link based on rationally acting agents between the amount of aid inflow and a slower and lower repayment pattern has to the best of our knowledge not previously been explored.

To fill this gap, this paper therefore explores whether inflows of foreign aid have on balance led to larger debt burdens and reduced repayment volumes. In order to approach an answer to this question, one therefore has to solve an endogeneity problem. We do this by employing a set of standard instruments for foreign aid in a series of panel estimates of debt service. We thereby sidestep the problem of measuring debt relief, as all actual relief is entailed in the stock data that we estimate debt service against. Exploring the determinants of debt service, we find that foreign aid strongly undermines developing countries' incentives to timely repayment of both total and publically guaranteed debts. We also test whether effects differ across regimes and political or economic 
circumstances. Our only robust finding is that countries that tend to vote predominantly with the US in the United Nations General Assembly are substantially less affected in their debt servicing schedule by inflows of foreign aid. We conclude the paper by briefly discussing the political consequence of the findings.

\section{Theory}

It is a long studied paradox of economics, and development economics in particular, that commercial financial institutions would lend money to third-world governments that are not clearly and officially committed to timely repayment, seemingly knowing that repayment will be slow and uncertain. Previous theoretical contributions have dealt with this issue by assuming systematical errors that extend to both lenders and borrowers. Feeny and McGillivray's (2003) theoretical considerations are a case in point, as they attribute the massive debt problems of HIPCs to political misconceptions of the social benefits of investments. However, while they do not note so, this explanation requires that both parties to a loan misconceive or misestimate the social benefits of the investment that the loan is supposed to finance. It also requires that the loan is actually used to finance an investment instead of other, potentially more popular public spending.

The validity of this latter assumption is rejected by most studies in the aid literature (e.g., Boone, 1996; Remmer, 2004; Rajan and Subramanian, 2008). Second, the validity of the misconception assumption and the implicit assumption that most politicians are benevolent is also debatable. Finally, it remains an open question how and why the presence of foreign aid - a potential substitute for receiving loans in an international market - affects the repayment discipline of indebted third-world governments.

In the following, we outline a relatively simple model that shows how rational behaviour on the part of both creditors and debtors can create a bargaining situation that offers one explanation for the observed bad debt servicing in connection with debtors access to foreign aid. The model discusses 
these issues within the simple framework of a war of attrition. Both parties - say an international foreign bank (subsequently called bank) and a third world country's government - are assumed to benefit from large scale financing of development projects at market terms. Yet, while the borrowing country or a sufficiently large political elite within the country benefits from increased debt financed investments as a growth strategy - or whatever activity that the loan actually finances - it will also want to avoid costly reforms (say the implementation of taxes) or cuts of popular spending needed to service their sovereign debt with a speedy repayment schedule. The bank, however, benefits more from lending money to governments of committed countries compared to countries not officially committing to regular and timely repayment. Banks endeavor, therefore, to pressure the prospective borrowers to clear commitment, which may require substantial reform or other unpopular policies and re-prioritizing, in order to maximize loan repayment and hence their benefits from lending out money. However, since the banking sector may also have some (surely smaller) benefits from borrowing money to noncommitted governments, say at a slower repayment schedule or with an increased risk of having to reschedule the debt, it may find itself unable to enforce its commitment demands, and it may eventually prove willing to extend loans without clear commitments from borrowers. In other words, banks do not have access to sufficiently credible threats to enforce their preferred loan conditions. ${ }^{2}$

We model the problem as a waiting game, where the players will endure delay, attempt to send certain signals as to their preferences, or try to display patience and indifference with respect to the final outcome, thus attempting to force their opponent into compliance. The game is won by the player willing to wait the longest for his favorite outcome to materialize. When adding into this an outside

\footnotetext{
${ }^{2}$ Note that since we are mainly interested in repayment behaviour, we assume that banks always have a sufficient incentive to extend loans to non-committed countries. While this is obviously not always the case, banks may still extend loans to risky borrowers as part of an optimal international portfolio. Likewise, we ignore any complications that may arise due to competition among banks, implicitly assuming some level of coordination of actions and information among international financial institutions.
} 
financing event - the possible inflow of foreign aid - we obtain a novel perspective on the seemingly paradoxical borrowing patterns and payment moral observed in developing countries.

\subsection{The base-line framework}

We consider a developing country or the negotiating government, $G$, and an international financial institution, $B$, that play a war of attrition type game concerning debt and repayment commitment. The bank, $B$, can unilaterally decide to lend money, in particular it can offer large-scale financial resources. $B$ has - in some initial step - outlined the necessary repayment scheme and ancillary commitments to be committed to by borrowers, but is unable to enforce any ex ante commitment to this scheme directly except by postponing financing. The applicant strives to achieve financial resources and decides to implement or not to implement the required commitment.

Both parties, $G$ and $B$, benefit from the financing and implementation of large scale projects. In the status quo - no official commitment and no financing - the payoffs from sovereign debt for both players are normalized to zero. Any change from the status quo results in the following present value payoffs, (which may or may not be known to the parties). The gains to $B$ from large scale finance are $a$. The total costs of borrowing large resources to a non-committed country (the slow repayment schedule) are given by $\sigma$. The gains to the country, $G$, from switching from the status quo (no borrowing) to large scale borrowing are $\beta$. The present value of all costs that the government faces when implementing and committing to full compliance with the bank's repayment requirements - net of the benefits that may stem from whatever reforms, policy changes or other arrangements are associated with commitment - is $\tau$. One can for example think of $\tau$ as the additional, unpopular taxes the government needs to impose on its constituency in order to meet the repayment requirements.

In addition, the country may receive foreign aid $u$, depending on it either having insufficient financial resources or sufficiently clearly signaling that it is in such a situation. Finally, we capture regime instability, say the risk of a political coup or uncertain election outcomes by the probability $\varphi$ of 
the current government (negotiator on behave of the developing country) being ousted from power. Nature plays $\varphi$ after each round of the game. The game ends and both $G$ and $B$ forego all benefits if the event occurs, $G$ because a new entity takes over control in the country, and $B$ because new negotiations with a new country or government have to be launched. All parameters $a, \sigma, \beta, \tau, u, \varphi>0$. The payoff structure is summarized in Figure 1.

Insert Figure 1 about here

The sequence of the game is as follows:

Step 0: $B$ states commitment requirements and opens a financing round.

Step 1: $G$ chooses to commit or not to commit.

Step 2: B chooses to lend or not to lend.

Step 3: Nature plays $\varphi$.

If large scale financing is postponed, the game is repeated with probability $1-\varphi$ or ends with probability $\varphi$. If large scale financing occurs, payoffs are realized and the game ends. Thus the game ends - possibly after some periods of delay - with either large scale financing or with a regime switch (after which the game could start again, albeit with a new player $G$ - we exclude this extension).

From the sequence and payoffs of this game, it immediately follows that once the developing country has implemented the commitment requirements, the bank's best strategy is to proceed with financing all the loan requests of the country; thus the situation (step one: commit; step two: do not lend money) is not an equilibrium. In fact, in the one-shot game with $a>\sigma$, lend is the bank's dominant strategy and accordingly, the game would end in the (do not commit; lend money) equilibrium, regardless of $\beta$ and $\tau$. On the other hand, in case $a<\sigma$, no bank would ever lend money to a country with this characteristic, which would render the model trivial. In the remainder, we therefore assume 
that $a>\sigma$ and $\beta>\tau+u$. In particular the latter assumption implies that receiving a large foreign loan is more attractive for the negotiating developing country than avoiding the economic or political costs of commitment and the loss of foreign aid (subsequently to receiving a large financial inflow). In the opposite case of $\beta-\tau<u$, the developing country government would prefer the status quo with foreign aid over the situation of project finance from commercial banks. Although one could argue that this latter scenario might be true for certain countries at certain times, it is not the constellation studied here - in fact it may mirror constellations closer to those emphasized in Mayr (2010).

The dynamics of this setup, which are at the center of the current paper, emerge in the repeated version, where both players have the power to end the game: the developing country, $G$, by committing to timely repayment and the bank, $B$, by lending to a non-committed government. Yet by not committing and postponing any lending activity, the players may choose to wait and delay the game in the hope that the other player will subsequently give up, thus allowing their own favorite outcome to materialize. $^{3}$

However, waiting is costly as players discount the future. Payoffs realized in subsequent periods are discounted at the rate of time preference $\rho \varrho_{j}$ with $j=G, B$ for the applicant and the bank respectively. This gives players a discount factor of $(1-\varphi) /\left(1+\varrho_{j}\right)$. Even though waiting is costly for both players, they are each willing to wait a certain period of time hoping for the other player to give up. This war of attrition is won by the player willing to wait the longest for his favorite outcome to occur (see Bliss and Nalebuff, 1984).

The structure of this game, of course, relies on a set of simplifying assumptions in order to generate a tractable framework. We want to comment on several of these assumptions. First, we model the situation as one between only one bank and one country. This is obviously unrealistic since there is

\footnotetext{
${ }^{3}$ The bank's favorite outcome is to lend to a committed country (payoff $a$ ) while the developing country government's favorite outcome is to obtain financing without committing to a timely repayment scheme (payoff $\beta$ ).
} 
a number of large international banks as well as international financial institutions that all extend loans to low and middle-income countries. However, our bank's behavior arguably does not differ from that of multiple banks and institutions with similar incentives and information and from banks that perceive themselves in competitive environments, bidding for various projects. We do nevertheless stress that in real life, we empirically observe various states of this game simultaneously.

Second, in our payoff structure the country stops receiving foreign aid as soon as market-based financial resources are committed. While this without doubt is not generally the case, it services us here to highlight the causality of our explanation, where aid causes loan agreements with lenient repayment conditions, and not the other way around, where bad payees are awarded larger aid flows, as in, e.g., Mayr (2010). Notice also, that we would obtain the same qualitative results as long as we have a reduction in the level of the foreign aid inflows. Third, we model the game in the form of repeated loan negotiations including the risk of negotiation collapse. In reality, such negotiations will not take place in rounds, nor do doors close indefinitely. Still, to capture the underlying structure this stark assumption is useful. Finally, part of the foreign loan inflow as well as aid may stem from one and the same foreign government. Here we have separated these entities, focusing only on the bank as a player and let foreign aid enter the game in the disguise of "nature". Were these two entities coordinated in the game (which they need not be although they belong to the same lender), the externality of foreign aid (by strengthening the developing countries negotiation stance) would obviously be accounted for.

\subsection{Maximum waiting times}

Since the war of attrition is won by the player willing to forego his winning payoff longer than his opponent, the maximum waiting times must be established. But even though agents are willing to wait, there need not be any delay. In effect, given the use of pure strategies only and a situation of complete information, there will be no substantial delay. Rather, the player who realizes that he will lose eventually will give up right away and harvest his losing payoff instead of enduring any delay and 
staying in the status quo (see Hendricks et al., 1988). On the other hand, in settings of incomplete information the game will feature some delay until the more patient agent has credibly established his willingness to wait (Alesina and Drazen, 1991). What is important for our analysis is to examine how the maximum waiting times of the bank and the government of the developing country are affected by the various parameters of the model, in particular the foreign aid payment, $u$. The maximum waiting time, $t_{B}$, of the bank is defined by equating the value of winning the bargaining game in the future and the value of giving up immediately:

$$
\alpha\left(\frac{1-\phi}{1+\rho_{B}}\right)^{t_{B}}=\alpha-\sigma
$$

The right-hand side is simply the present value of giving up right away, i.e. lending to an unclearly committed country with a slow repayment schedule. On the left-hand side, we have the present value to the bank of the developing country giving in and fulfilling the commitment requirements (with subsequent borrowing activity) at time $t_{B}$. From (1) the maximum waiting time of the bank is given by:

$$
t_{B}=\ln \left(\frac{\alpha-\sigma}{\alpha}\right) \ln \left(\frac{1-\phi}{1+\rho_{B}}\right)^{-1}
$$

Parallel, the problem of the developing country government can be stated by equating the favorite outcome at time $t_{G}$ with giving up immediately:

$$
u+(\beta-u)\left(\frac{1-\phi}{1+\rho_{G}}\right)^{t_{G}}=\beta-\tau
$$

The left-hand side is the value of winning at time $t_{A}$, while the right-hand side is the value of giving up today, i.e. fulfilling the commitment requirements and receiving loan finance immediately. From (3) the maximum waiting time of the developing country is:

$$
t_{G}=\ln \left(\frac{\beta-\tau-u}{\beta-u}\right) \ln \left(\frac{1-\phi}{1+\rho_{G}}\right)^{-1}
$$


Due to the sequential nature of the game, when the developing country plays 'tough' i.e. does not fulfill the commitment requirements, the bank, if it decides to postpone the commitment of large scale financing (punish the non-committed country), can at best achieve its favorite outcome (lending to an officially committed country) in the next round of the game. Formally we can state:

Lemma 1. The Bank wins the lending game if $t_{B}>t_{G}+1$, resulting in the country abiding by the repayment requirements and large scale lending taking place.

The reasoning of Lemma (1) is the common intuition behind the war of attrition whereby the player that can establish that he is willing to wait longer than his opponent - either by demonstrating his ability to wait (incomplete information) or because his ability to wait is known (complete information) - wins the game. He does so because the other player, after recognizing the other's superior ability to hold out longer, maximizes his payoff by giving up straight away (see Bliss and Nalebuff 1984; Alesina and Drazen, 1991; Hendricks et al., 1988).

\subsection{Bank and country parameters with foreign aid}

When differentiating $t_{B}$ and $t_{G}$ with respect to the gain, cost and time preference parameters of the two players, the standard war of attrition results are obtained. Formally, for the maximum waiting time of the bank we can state:

Proposition 1. The bank's maximum waiting time $t_{B}$ increases, i.e. the bank's chances of winning - the developing country abiding by the scheduled repayment requirements and large scale finance taking place - increase, when ceteris paribus:

i) the bank's benefits from lending, a, decrease

ii) the bank's costs of lending to non-committed countries, $\sigma$, increase 
iii) the bank becomes more patient, i.e. $\varrho_{B}$ decreases

iv) regime stability increases, i.e. $\varphi$ decreases

The derivatives of $t_{B}$ are presented in the Appendix. What is stated as Proposition 1 follows a clear intuition. If the bank is too eager to lend money, it reduces its chances of being able to pressure for complete commitment to the required repayment scheme. This eagerness may well be the result of the competitive situation among several banks on the market, but it is not examined here. On the other hand, as the costs of lending to non-committed countries increase, the bank has a stronger standing in negotiations. Finally, patience - as always in the war of attrition - is a good strategy for winning the game.

Next, the maximum waiting time of the developing country government can be examined in the same fashion. The following parallel results can be stated:

Proposition 2. The developing country's maximum waiting time $t_{G}$ increases, i.e. the government's chances of winningborrowing large scale financial resources without having abided by the required repayment scheme (slow repayment schedule) - increase, when ceteris paribus:

i) the country's benefits from the loan, $\beta$, decrease

ii) the country's costs of following the required repayment scheme, $\tau$, increase

iii) the country becomes more patient, i.e. $\varrho_{A}$ decreases

iv) regime stability increases, i.e. $\varphi$ decreases

v) the country receives more foreign aid, i.e. $u$ increases

The derivatives of $t_{G}$ are presented in the Appendix. Proposition 2 also displays a clear intuition: for example, countries that benefit significantly from loan finance (e.g. higher local return projects) can be more easily forced to fulfill all the requirements set out. Conversely, countries with access to 
alternative finance (e.g. short-term loans) are less likely to fulfill the requirements, as their relative benefits are smaller.

Centrally, what Proposition 2 states is that the presence of foreign aid will increase the chances that the developing country government can outwait the bank and receive financial resources while repaying at a slow repayment schedule. The reason is that by easing pressure in the current status quo, the government becomes less prepared to commit to the potentially costly requirements needed to attract finance. Thus equipped with "aid financed" patience, banks in this stylized game have no better option but to lend money to uncommitted governments, risking slow or only partial loan repayment.

\subsection{Political instability}

One further result emerges from the comparison of the above results. Part of the aid literature emphasizes the special problems facing relatively unstable political regimes and governments (e.g. Chauvet, 2002; Chauvet and Guillamont, 2001). In our model, the regime stability parameter, $\varphi$, enters both $t_{B}$ and $t_{G}$. This causes the following.

Corollary 1. An increase in regime stability, i.e. a reduction in $\varphi$, increases both maximum waiting times $t_{B}$ and $t_{G}$, and the effect of increased regime stability on the game outcome is in general undetermined.

The rationale is that both players react with longer waiting times in response to a more stable political environment, and shorter waiting times in response to more volatile regime conditions. With more instability, the bank risks investing in attrition for nothing, if a new government in the developing country restarts the game. Likewise, instable regimes in developing countries risk not living long enough to realize the benefits of loans.

This implies a hypothesis that political regime stability has only ambiguous effects on debt repayment patterns. In general, the size of the effect on each player's waiting time will determine who 
improves the chances of winning, and this effect will in turn depend on the involved win-lose ratios at stake. Put differently, if banks' win-lose ratios are small, i.e. close to indifference, an increase in political stability will increase its chances of outwaiting the developing country government, resulting in more strict repayment agreements. This would also be the case, if we allow the bank to turn to multiple other finance opportunities. Similarly, if the developing country has a relatively low win-lose ratio, i.e. the "with finance" versus "without finance" state results in similar outcomes, then the increased regime stability will benefit the government in boosting its ability to outwait the bank and arrive at a lenient debt repayment schedule. As both 'pure' political instability in the form of coups and revolutions as well as democratic instability in the form of not re-electing incumbent government contribute to the necessary government uncertainty, we note that the effects of regime type are also ambiguous.

In the following, we explore these testable implications, focusing on those associated with foreign aid. The next section outlines the data employed in our empirical analysis.

\section{Data}

The core data used for this purpose are all from the World Bank (2010) World Development Indicators database. We supplement these data with relevant data from other sources.

The central variables are constructed from two measures of debt service and outstanding debts. The first measures private nonguaranteed external debt, comprised of all "long-term external obligations of private debtors that are not guaranteed for repayment by a public entity" (World Bank, 2010). The second measures public and publicly guaranteed debt, comprised of all "long-term external obligations of public debtors, including the national government, political subdivisions (or an agency of either), and autonomous public bodies, and external obligations of private debtors that are guaranteed for repayment by a public entity" (World Bank, 2010). We use the second on its own and add the two measures to get total levels of external debt, and the annual service of that debt, both as percent of GNI. 
Our other main variable, foreign aid, is measured as Official Development Aid (ODA), defined as aid provided by official agencies with the aim of promoting economic development and welfare, and conveying a grant element of at least 25 percent (OECD, 2007). While it is often a worry that ODA includes both aid and loans with large grant elements, this is not likely to be so in this paper, as the pure loan component of ODA is necessarily captured in the stock of external debts. We measure these inflows as debts, as percent of GNI.

We supplement this with a specification consisting of the following variables. From the same World Development Indicators database, we add GNI per capita in purchasing power adjusted US Dollars, trade volumes (percent of GDP), Foreign Direct Investments (FDI in percent of GDP), and government general consumption (percent of GDP). We add exchange rate appreciation, as measured as the percent increase in the exchange rate to the US dollar, based on the data in Heston et al. (2009). While some debt may be denoted in other currencies, the large majority of foreign loans are denoted in dollars. The real value of debts, in terms of the national currency, therefore appreciates with the dollar exchange rate. From this, we also calculate the share of non-guaranteed debt in total external debts, as well as the share of total debts that are short-term (i.e., with debt with a term shorter than one year). This particular variable proxies for countries' ability to refloat debts instead of entering into the kind of negotiations considered in the theoretical part.

The specification also includes a number of political / institutional variables. We follow the minimalist approach in Cheibub et al. (2010) in measuring democracy as a simple dummy measuring whether or not the country has had free, fair and contested elections. Democracy is alternatively measured by Vreeland's (2008) Xpolity, which is a correction of the standard Polity IV index that takes out indicators of violence that are arguably not associated with political institutions. ${ }^{4}$ Xpolity still

\footnotetext{
${ }^{4}$ While Xpolity may capture more relevant characteristics of political institutions, such as constraints on the executive as emphasized by Acemoglu and Robinson (2006), it is arguably a problematic index as is the original Polity IV set (Vreeland,
} 
applies a minimalist definition of democracy, but includes more elements of contestability and constraints on the executive, which may be more informative when trying to separate purely electoral and liberal democracies (Møller, 2007). As outlined above, repayment incentives may not only depend on regime characteristics, but also depend on the stability of the regime. Not least, governments may spend additional resources on staying in power whenever the opposition is a real threat. Likewise, autocratic governments may spend more on reducing dissatisfaction with the regime and quelling resistance. In both cases, part of the additional spending may be diverted from paying off foreign debts. Apart from controlling for democracy, we proxy political stability with either the number of successful coup d'etats in each five-year period, or the number of all successful, failed, or confirmed planned coups, based on information the dataset in Marshall and Marshall (2009).

In addition, we control for three further sets of political factors. First, we include the number of years within a five-year period that a country had a seat on the United Nations Security Council. This inclusion is potentially important as Kuziemko and Werker (2006) and Dreher et al. (2009) show that donors' behaviour towards developing countries receiving foreign aid tends to change when recipients hold a seat on the UNSC.

Second, we proxy for the ideological orientation of the government and the traditional ideological orientation of politics in a given country by including the share of votes in the United Nations General Assembly in every five-year period in which the country voted with the US. While a direct measure of government ideology would have been preferable, such measures are unavailable for most developing countries. ${ }^{5}$ Instead, the degree to which a developing country government agrees with the US in matters

2008; Cheibub et al., 2010). In particular, both indices fail to adequately measure the participation dimension of democracy (cf. Munck and Verkuilen, 2002). It also does not cover many smaller countries in the Cheibub et al. (2010) dataset.

${ }^{5}$ Some developing countries are included in the World Bank Database of Political Institutions (Beck et al., 2001). However, these measures are highly imprecise and party placement is questionable in many cases. As a consequence, Bjørnskov (2008), constructing an ideology measure from the Database of Political Institutions, only considers fully democratic countries for 
of international politics may be taken as a valid proxy for their degree of support for a free-market capitalist economy, including the obligation to repay foreign loans. Conversely, countries voting with the opponents of the US may find it easier to renegotiate loan conditions, effectively ignoring international economic governance. These countries often form a large majority among developing countries and therefore may carry significant joint weight in the United Nations and other international organizations, and are otherwise treated differently due to their voting behaviour (Dreher et al., 2008). These data are from the Voeten (2004) dataset, calculated as the share of votes with the US, given that the US did not abstain from voting on an issue. We therefore follow Kegley and Hook (1991) in discarding abstentions.

Finally, we add dummies for whether countries have joined the HIPC Initiative, and whether they were included in the primarily US-led debt rescheduling schemes of the late 1980s and early 1990s known as the Baker and Brady Plans (Erbe, 1986; Devlin, 1990). We would strongly expect these plans to affect repayment behaviour, given that they achieved what they were supposed to, which was to "accelerate the negotiation of debt reduction, but also enhance the terms for the debtors, since there would be a more competitive environment on account of the developing country's ability to negotiate bilaterally with its different creditors" (Devlin, 1990, 83). The inclusion in such politically designed rescheduling or debt reduction plans may therefore change developing countries' incentives to commit to timely repayment, as a credible, international back-up option comes into existence. Consistent with the model in section 2, these changes may nonetheless not be consistent with the aims of the plans.

We estimate the determinants of repayment of total and publically guaranteed debts, using a standard random effects instrumental variables estimator. While Hausman tests are sometimes significant and sometimes not, indicating casual support for the use of a fixed effects estimator since random effects may produce inconsistent estimates, we opt for reporting the more efficient random

which somewhat better data are available. For a sample of OECD countries with reasonably precise ideology data, Potrafke (2009) shows that UNGA voting and government ideology correlate significantly. 
effects estimates throughout. The reason is that while the point estimates of FDI and the HIPC dummy tend to differ significantly between estimators, all other estimates remain the same and our central estimates always appear consistent. In all cases, we jackknife the standard errors to minimize the influence of potential outlier observations.

To control for the possibility explored in Mayr (2010) that aid inflows may be sensitive to debt repayment incentives and service, we employ instrumental variables. Our instruments for foreign aid are the logarithm to population size and life expectancy at birth, both taken from the World Development Indicators database. We provide a test of instrument validity, the Hansen J-statistic of overidentification, throughout. In addition, we note that underidentification, i.e. weak instruments, is not likely to be a problem since most first-stage statistics are of similar magnitude as those in the second stage. ${ }^{6}$

\section{Main results}

We begin by looking at simple averages across the six five-year periods covered in the paper. As in other papers, the pattern over time is suggestive of an overall negative association between foreign aid and debt service. While inflows of foreign aid (percent of GNI) increased throughout the 1990s, the debt service record deteriorated (as a percent of total debts). As foreign aid to developing countries decreased sharply in the early 1990s, partly due to aid fatigue and partly to the perceived need of formerly communist countries in Central and Eastern Europe, the development of developing

\footnotetext{
${ }^{6}$ We recognize that instrumental variables estimates in the presence of heterogeneous effects of the instrumented variable or heterogeneous effects of the instruments may be biased (e.g. Dunning, 2008). However, we are forced to assume that this is not a major problem since we have no way of alleviating it in a consistent and valid way. We nevertheless note that although we provide results with three somewhat different samples, there is no indication that the instruments perform better in any particular sample.
} 
countries' debt service records stagnated and eventually improved slightly from the beginning of the new millennium. While this points to a negative overall association, we cannot tell from such simple plots whether the association is spurious or causal in one or the other direction. We therefore turn to a set of IV random effects estimates.

\section{Insert Figure 2 about bere}

We report the results of our baseline specification in Table 2, using three different cut-offs of GNI per capita to define developing countries. In columns 1 and 4, we include all available countryperiod observations with a GNI per capita below 10,000 USD (2005 prices). In recent years, this cutoff only excludes a group of countries including South Africa, Swaziland and a number of Latin American countries, i.e. countries that have clearly graduated to middle-income status. In columns 2 and 5, the cut-off is 7000 USD, and in columns 3 and 6, we apply a cut-off of 5000 USD. This way, we ensure that our findings generalize to aid recipients instead of groups of countries with either very low average incomes or select problems.

Starting with the economic control variables, we note that neither GNI, FDI nor exchange rate appreciation are significant while trade is strongly significant throughout. Among the political variables the vote share with the US is significant and quantitatively important throughout Table 2 . Having a seat on the UNSC during a five-year period also alters repayment behaviour, although in a positive direction. Whether this is an effect of being on the council or that more politically trustworthy countries are more likely to be selected to the council is nevertheless uncertain. Conversely, while one could hope that democracy affects repayment incentives, this is never significant. Neither is the other source of political stability, coups, confirming our theoretical ambiguity. ${ }^{7}$

\footnotetext{
${ }^{7}$ It bears mention that we have experimented with other measures of, e.g., civil war and international violence. None of these measures were significant.
} 
Turning to our directly debt-related variables, we find that countries with larger debts (naturally) repay larger shares of GNI. This effect is nevertheless stronger for total debt levels than for servicing guaranteed debt. As such, the difference is consistent with countries paying higher effective interest rates on non-guaranteed debt. On the one hand, we find that countries with a small share of their debts being guaranteed have apparently opted for faster repayment schedules, or are more likely to have credibly committed to such schedules. On the other hand, countries with larger stocks of short-term debts repay relatively smaller annual shares of GNI. This latter finding could reflect countries' political patience, as in Proposition 2.iii, or banks' impatience with specific countries, as in 1.iii. Finally, we note that while the Baker and Brady plans did not affect repayment behaviour, countries in the HIPC Initiative tend to repay substantially smaller amounts. Yet, by comparing across columns, this effect is clearly driven by the relatively richer members of the initiative.

Turning to our main aim, we find throughout the table that larger inflows of foreign aid are significantly associated with lower repayment rates. This association is likely to be causal, as our instruments pass Hansen's J Statistic test in all cases, and in most cases with a rather considerable margin. ${ }^{8}$ For total debts, a one-standard deviation change in foreign aid - roughly 10 percent - is associated with a reduction in debt servicing of about 60 percent of a standard deviation. For guaranteed debts, a similar increase in foreign aid induces a reduction in debt servicing of about 75 percent of a standard deviation. As such, the effects of foreign aid on debt repayment behaviour are rather substantial.

These effects are not likely to be caused by misspecification of the politically most relevant variables, as shown in Table 5. Adding countries' voting record with Russia in the UNGA obviously introduces a multicollinearity problem with US voting, but does not affect our central estimates. While the standard errors of the effect of voting with the US are inflated, the point estimates remain

\footnotetext{
${ }^{8}$ In addition, all first stage F statistics for the instruments are above those of the second stage. We are therefore not likely to face an underidentification problem.
} 
quantitatively similar. Neither does the replacement of the number of all coups with the number of successful coups, or the application of a broader democracy measure.

Another worry would be that the central estimates are driven by observations in the tails of the distribution. If so, our results may be suggestive of problems at excessive (or insufficient) inflows of foreign aid, extreme debt burdens or unusual debt repayment behaviour. By excluding the ten percent of our observations with the largest inflows of foreign aid (>21 percent of GNI) and the ten percent with the smallest inflows $(<.3$ percent of GNI) in columns 4 and 8 , we nevertheless obtain qualitatively similar results. If anything, excluding the most aid-dependent countries from the sample tend to yield even larger effects of foreign aid on debt service while excluding observations with very large debt repayments yields a somewhat smaller, but still significant, effect of aid.

\section{Are unstable or democratic developing countries different?}

We have carefully tried to control the causal direction of this association, and shown that the findings are not driven by observations in the thin tails of the distributions of foreign aid and debts. Yet, we have assumed so far that the effects of foreign aid are homogenous across countries, regimes and circumstances. However, based on our simple theoretical exploration, it would seem likely that regimes with shorter effective time horizons would have weaker bargaining positions vis-a-vis lenders, and would therefore be forced to commit to clear repayment schedules. Conversely, intuitively one would expect that regimes with shorter effective time horizons would have weaker incentives to abide by those commitments when inflows of foreign aid are likely. As such, we would expect that the repayment incentives of politically unstable regimes would be more sensitive to inflows of foreign aid, all other things being equal, although we cannot be theoretically sure of the sign of the net effects.

Likewise, it is often assumed that democracies behave differently, as the electoral institutions of democracy are accompanied by executive constraints with the purpose of underpinning the fiscal 
credibility of the regime. ' Given this, democracies' ability to credibly commit to timely repayment would seem higher. Furthermore, since governments can be voted out of power, their bargaining position vis-a-vis lenders would seem weaker, as the politically relevant time horizons are shorter. Conversely, relatively stable autocratic governments will arguably have longer time horizons than democratic governments that face re-election considerations. Both factors would tend to lead us to expect that democracies are more likely to commit to timely repayment while politically unstable countries may have weaker bargaining positions, but also weaker ability to credibly commit.

At a broader level, Reinhart and Rogoff (2009) define debt-intolerant regimes as countries with deficient institutions, be it instable regimes or incomplete checks and balances on political power. Such regime characteristics, they argue, are relevant to understanding how large debt burdens countries can service. Yet, as outlined in section 2.4, international financial institutions facing instable regimes may have a strong incentive to close a deal before the regime is ousted. In this case, banks' patience is short, which undermines their bargaining position. It is this two-sided effect of political instability that makes the prediction ambiguous. In addition, it should be noted that, as argued by Bjørnskov (2010), Western donor organizations may tend to be more lenient towards democratic regimes, which would, all other things being equal, tend in the same direction as banks' problems. This difference may also pertain to banks and other financial institutions if such institutions - correctly or not - believe democratic governments to be either more fiscally responsible or more likely to be bailed out by donor countries.

The simple differences in our data confirm that non-democracies tend to have slightly higher levels of debt, although not significantly different debt repayment shares. Countries that have experienced coups also seem to opt for slower repayment schedules although they face no higher debt

\footnotetext{
${ }^{9}$ In one of the most famous papers on institutions, North and Weingast (1989) argue that the credibility of debt obligations was one of the significant results of the Glorious Revolution in the United Kingdom. Ferguson (2002) similarly argues that the credibility and security of British government bonds was instrumental in securing the military and commercial superiority of the UK over the larger French and Spanish regimes in the $18^{\text {th }}$ and $19^{\text {th }}$ centuries.
} 
levels. We therefore interact the indices of democracy and regime instability with aid inflows. We also add the intuitively appealing interactions with Xpolity - our broader measure of democracy - as well as the degree of exchange rate appreciation and the US vote shares. By interacting aid with democracy or other institutional characteristics, we effectively test whether 'debt intolerant' regimes react differently to inflows of aid. We follow Reinhart and $\operatorname{Rogoff}(2009,21)$ in defining debt intolerance as a situation "in which weak institutional structures and a problematic political system make external borrowing a tempting device for governments to avoid hard decisions about funding and taxing". The results are reported in Table 5.

\section{Insert Table 5 about here}

The results provide some suggestive support for the theoretical notion that the repayment effect of aid inflows depends on country characteristics that would affect countries' political patience or their willingness to commit to timely repayment. On the one hand, aid effects in general seem larger when there have been coups or coup attempts and in democracies, both situations which would tend to shorten the politically relevant time horizon of the regimes. On the other hand, the aid effect turns insignificant at the very tails of appreciation and US vote distributions. While the lack of significance of aid at extreme levels of exchange rate appreciation is most likely an effect of an extremely thin tail - i.e. very few observations at the end of the distribution - the finding that the effect of aid on repayment behaviour is in general decreasing with the share of votes in the UNGA that the country cast with the US cannot be dismissed on the same account. Some countries may evidently be debt-intolerant, yet the present results appear to indicate that such intolerance is more to do with international politics than domestic institutions. With evidence on the robustness of the results, we proceed to discuss them in the final section. 


\section{Conclusions}

This paper started with the question why poor countries can run up excessive external debts with foreign banks that seemingly should know that loan repayment will be slow and risky. We have proposed a rational choice perspective, highlighting the potential interference of foreign aid with the loan negotiation between third-world countries and international financiers. We model this interaction as a war of attrition, where both the third world government and an international bank can hold each other hostage over the agreement on large-scale finance. Patience, as always in a war of attrition, is the key to winning this negotiation game. With foreign aid, third world country patience is boosted, increasing their chances of winning the negotiation game and arriving at lenient loan repayment conditions. We take this perspective to the data. In a newly constructed data set controlling for items such as trade openness, democracy, political ideological positions, political stability and other development indicators, we regress the speed of debt repayment among 93 developing countries in the period from 1980 to 2005. For all our specifications and both total and publically guaranteed debts, we find that the presence of foreign aid reduces the speed and discipline of debt servicing.

The negative association between aid inflows and debt service could, in principle, be a pure reflection effect, if objective problems that restrict developing countries' ability to repay loans induced large aid inflows. Yet, we do not believe that the association between aid and debt service is likely to reflect confounding events, such as economic, social or political crisis. If so, we would have expected the effects of economic crisis to be reflected in GNI per capita or exchange rate movements, and political crisis to be reflected in changes in democratic status, instability as measured by coups, and most likely also in FDI, which tends to dry up in times of acute crisis. None of these variables are significant. We therefore take the association between aid and actual debt servicing to reflect an effect of aid on repayment incentives. Furthermore, had aid affected repayment ability, we would have expected a positive sign, contrary to the strongly negative and significant effect we obtain. 
Our findings therefore have implications for international debt policy. Most campaigns and debt relief initiatives couple substantial debt relief with increased inflows of foreign aid. However, in order to achieve sustainable levels of foreign debts, such initiatives probably ought to provide incentives for timely repayment of remaining debts. Our results provide evidence suggesting that the coupling of debt relief and foreign aid in most initiatives is counterproductive in the sense that the aid component undermines repayment incentives, contrary to what most development practicians seem to think (e.g. Ndikumana, 2004). This type of effect may be the reason for our finding that inclusion in the HIPC Initiative, even before any country graduated to actual debt relief, has been associated with substantially lower repayment rates. If the association is not evidence of selection by bad payees into the initiative, an alternative explanation consistent with our theoretical story is that inclusion substantially improved member countries' negotiation position vis-a-vis their creditors.

While our results suggest that such adverse effects of well-meaning political initiatives need to be taken into account in order to make them 'work', we necessarily leave a set of questions for future research. For example, we find no differences in repayment behaviour across the immediately observable regime characteristics; neither do we find differences in the marginal effect of aid across such characteristics. However, from an intuitive theoretical perspective, regime and institutional characteristics ought to affect repayment incentives and behaviour. Future research may well look into which regime characteristics determine repayment behaviour. Likewise, we have treated all creditors as one although there may arguably be differences across institutional and private creditors. Whether such differences exist and if the mix and fractionalization of creditors matter is also an issue we leave for future research.

\section{Appendix A.1: Derivatives in Proposition 1}

We here provide derivatives of the Bank's maximum waiting time. Differentiating $\mathrm{t}_{\mathrm{B}}$ given in (2) in the main text with respect to $\alpha, \sigma, \varphi$ and $\varrho_{\mathrm{E}}$ gives: 


$$
\frac{\delta t_{B}}{\delta \alpha}=\frac{o}{\alpha(\alpha-o)} \ln \left(\frac{1-\varphi}{1+\rho_{B}}\right)^{-1}
$$

which is negative, since the first term is positive and the second term is negative. Further,

$$
\frac{\delta t_{B}}{\delta o}=\frac{-1}{(\alpha-o)} \ln \left(\frac{1-\varphi}{1+\rho_{B}}\right)^{-1}
$$

which is positive, since both the first term and the second term are negative. Further,

$$
\frac{\delta t_{B}}{\delta \rho_{B}}=\frac{\ln \left(\frac{\alpha-o}{\alpha}\right)}{\left(1+\rho_{B}\right)} \ln \left(\frac{1-\varphi}{1+\rho_{B}}\right)^{-2}
$$

which is negative, since the numerator is negative while the denominator is positive. Finally,

$$
\frac{\delta t_{B}}{\delta \phi}=\frac{\ln \left(\frac{\alpha-o}{\alpha}\right)}{(1-\phi)} \ln \left(\frac{1-\varphi}{1+\rho_{B}}\right)^{-2}
$$

which is following (A3) negative.

\section{A.2: Derivatives in Proposition 2}

Fully parallel to Appendix A.1 the derivatives of the developing country's maximum waiting time can be stated. Differentiating $t_{G}$ given in (4) in the main text with respect to $\beta, \tau, \varrho_{G}, u$ and $\varphi$ gives:

$$
\frac{\delta t_{G}}{\delta \beta}=\frac{\tau}{(\beta-u)(\beta-u-\tau)} \ln \left(\frac{1-\varphi}{1+\rho_{G}}\right)^{-1}
$$

which is negative, since the first term is positive and the second term is negative. Further,

$$
\frac{\delta t_{G}}{\delta \tau}=\frac{-1}{(\beta-u-\tau)} \ln \left(\frac{1-\varphi}{1+\rho_{G}}\right)^{-1}
$$

which is positive, since both the first term and the second term are negative. Further, 


$$
\frac{\delta t_{G}}{\delta \rho_{G}}=\frac{\ln \left(\frac{\beta-u-\tau}{\beta-u}\right)}{\left(1+\rho_{G}\right)} \ln \left(\frac{1-\varphi}{1+\rho_{G}}\right)^{-2}
$$

which is negative, since the numerator is negative while the denominator is positive. Further,

$$
\frac{\delta t_{G}}{\delta \phi}=\frac{\ln \left(\frac{\beta-u-\tau}{\beta-u}\right)}{(1-\phi)} \ln \left(\frac{1-\phi}{1+\rho_{G}}\right)^{-2}
$$

which is negative, since the numerator is negative while the denominator is positive. Finally,

$$
\frac{\delta t_{G}}{\delta u}=\frac{-\tau}{(\beta-u)(\beta-u-\tau)} \ln \left(\frac{1-\varphi}{1+\rho_{G}}\right)^{-1}
$$

which is positive, since both the first term and the second term are negative.

\section{References}

Acemogly, Daron and James A. Robinson. 2006. Economic Backwardness in Political Perspective. American Political Science Review 100: 115-131.

Alesina, Alberto and Alan Drazen. 1991. Why are Stabilisations Delayed? American Economic Review, vol. $81,1170-88$.

Amador, Manuel. 2008. Sovereign Debt and the Tragedy of the Commons. Working paper, Stanford University.

Beck, Thorsten, George Clarke, Alberto Groff, Philip Keefer and Patrick Walsh. 2001. New Tools and New Tests in Comparative Political Economy: The Database of Political Institutions. World Bank Economic Review 15: 165-176.

Bjerg, Christina, Christian Bjørnskov and Anne Holm. In press. Growth, Debt Burdens and Alleviating Effects of Foreign Aid in Least Developed Countries. Forthcoming in European Journal of Political Economy. 
Bjørnskov, Christian. 2008. The Growth-Inequality Association: Government Ideology Matters. Journal of Development Economics, vol. 87, 300-308.

Bjørnskov, Christian. 2010. Do Elites Benefit from Democracy and Foreign Aid in Developing Countries? Journal of Development Economics, vol. 92, 115-124.

Boone, Peter. 1996. Politics and the Effectiveness of Foreign Aid. European Economic Review, vol. 40, 289-329.

Bliss, Christopher and Barry Nalebuff. 1984. Dragon-Slaying and Ballroom Dancing: The Private Supply of a Public Good. Journal of Public Economics, vol. 25, 1-12.

Brücker, Herbert, Philipp J.H. Schröder and Christian Weise. 2004. Doorkeepers and Gatecrashers:

EU Enlargement and Negotiation Strategies. Journal of European Integration, vol. 26, 3-24.

Bulow, Jeremy and Kenneth Rogoff. 1990. Cleaning up Third World Debt Without Getting Taken to the Cleaners. Journal of Economic Perspectives, vol. 4, 21-42.

Chauvet, Lisa. 2002. Socio-Political Instability and the Allocation of International Aid by Donors. European Journal of Political Economy, vol. 19, 33-59.

Chauvet, Lisa, and Patrick Guillamont. 2001. Aid and Performances: A Reassessment. Journal of Development Studies, vol. 37, 66-92.

Chauvin, Nicolas Depetris and Aart Kraay. 2007. Who Gets Debt Relief? Journal of the European Economic Association, vol. 5, 333-342.

Cheibub, José Antonio, Jennifer Gandhi and James Raymond Vreeland. 2010. Democracy and Dictatorship Revisited. Public Choice, vol. 143 (1-2), 67-101.

Collier, Paul and Anke Hoeffler. 2007. Unintended Consequences: Does Aid Promote Arms Races? Oxford Bulletin of Economics and Statistics, vol. 69 (1), 1-27.

Corden, W. M. 1984. Booming Sector and Dutch Disease Economics: Survey and Consolidation. Oxford Economic Papers, vol. 36(3), 359-380. 
Devlin, Robert. 1990. From Baker to Brady: Can the New Plan Work? Revista de Economia Politica, vol. $10,82-94$.

Doucouliagos, Hristos and Martin Paldam. 2008. Aid Effectiveness on Growth: A Meta Study. European Journal of Political Economy, vol. 24, 1-24.

Dreher, Axel, Peter Nunnenkamp and Rainer Thiele. 2008. Does US Aid buy UN General Assembly Votes? A Disaggregated Analysis. Public Choice, vol. 136, 139-164.

Dreher Axel, Jan-Egbert Sturm, and James Raymond Vreeland. 2009. Development Aid and International Politics: Does Membership on the UN Security Council Influence World Bank Decisions? Journal of Development Economics, vol. 88, 1-18.

Dunning, Thad. 2008. Model Specification in Instrumental Variables Regression. Political Analysis 16: $290-302$.

Easterly, William. 2002. How did the Heavily Indebted Poor Countries become Heavily Indebted? Reviewing 2 Decades of Debt Relief. World Development, vol. 30(10), 1677-1696.

Easterly, William, Ross Levine and David Roodman. 2004. New Data, New Doubts: A Comment on Burnside and Dollar's 'Aid, Policies, and Growth (2000)'. American Economic Review, vol. 94 (3), 774-780. Eaton, Jonathan, and Raquel Fernandez. 1995. Sovereign Debt, In: Gene M. Grossman and Kenneth Rogoff, Editor(s), Handbook of International Economics, Elsevier, vol. 3, 2031-2077.

Erbe, Rainer. 1986. Has the Baker Plan Failed? Intereconomics, vol. 21, 213-214.

Feeny, Simon and Mark McGillivray. 2003. Aid and Public Sector Borrowing in Developing Countries. Journal of International Development, vol. 15, 989-998.

Ferguson, Niall. 2002. The Cash Nexus: Money and Power in the Modern World, 1700-2000. New York, Basic Books.

Freytag, Andreas and Gernot Pehnelt. 2009. Debt Relief and Governance Quality in Developing Countries. World Development, vol. 37 (1), 62-80. 
Friedman, Milton. 1958. Foreign Economic Aid: Means and Objectives. Yale Review, vol. 47 (4), 500516.

Heinemann, Friedrich. 2000. Strategic Lessons from the Maastricht Criteria. Kredit und Kapital, vol. 33, 455-67.

Hendricks, Ken, Andrew Weiss and Charles A. Wilson. 1988. The War of Attrition in Continuous Time with Complete Information. International Economic Review, vol. 29, 663-80.

Heston, Alan, Robert Summers and Bettina Aten. 2009. Penn World Tables Version 6.3. Center for International Comparisons: University of Pennsylvania.

Hepp, Ralf. 2008. Can Debt Relief Buy Growth? Fordham Economics Discussion Paper 2008-22.

Imbeau, Louis (ed.). 2009. Do They Walk like They Talk? Speech and Action in Policy Processes. Springer:

Dordrecht.

Johansson, Pernilla. In press. Debt Relief, Investment and Growth. Forthcoming in World Development.

Kanbur, Ravi. 2000. Aid, Conditionality, and Debt in Africa. In Finn Tarp (ed.), Foreign Aid and

Development: Lessons Learnt and Directions for the Future. London: Routledge.

Kegley, Charles W. Jr., and Steven W. Hook. 1991. US Foreign Aid and UN voting: Did Reagan's Linkage Strategy buy Defense or Defiance? International Studies Quarterly, vol. 35, 295-312.

Knack, Stephen. 2001. Aid Dependence and the Quality of Government: Cross-Country Empirical Tests. Southern Economic Journal, vol. 68 (2), 310-329.

Knack, Stephen. 2004. Does Foreign Aid Promote Democracy? International Studies Quarterly, vol. 48, 251-266.

Kuziemko Ilyana and Eric Werker. 2006. How Much is a Seat on the Security Council Worth? Foreign Aid and Bribery at the United Nations. Journal of Political Economy, vol. 114, 905-930.

Marshall, Monty G. and Donna Ramsay Marshall. 2009. Coup d'Etat Events, 1946-2008. Codebook and data available at http://www.systemicpeace.org/inscr/inscr.htm (accessed May 2010). 
Mayr, Karin. 2010. Optimal Deficit and Debt in the Presence of Foreign Aid. World Development, vol. 38 (1), 19-27.

Moyo, Dambisa. 2009. Dead Aid: Why Aid Is Not Working and How There Is a Better Way for Africa. New York: Farrar, Straus and Giroux.

Mueller, Dennis. 2003. Public Choice III. Cambridge: Cambridge University Press.

Munck, Gerardo L. and Jay Verkuilen. 2002. Conceptualizing and Measuring Democracy: Evaluating Alternative Ideas. Comparative Political Studies 35, 5-34.

Møller, Jørgen. 2007. The Gap between Electoral and Liberal Democracy Revisited. Some Conceptual and Empirical Clarifications. Acta Politica, vol. 42, 380-400.

Ndikumana, Léonce. 2004. Additionality of Debt Relief and Debt Forgiveness, and Implications for Future Volumes of Official Assistance. International Review of Economics \& Finance, vol. 13, 325-240.

North, Douglass and Barry Weingast. 1989. Constitutions and Commitment: The Evolution of Institutions Governing Public Choice in Seventeenth-Century England. Journal of Economic History 49, 803-832.

OECD. 2007. Is it ODA? OECD Factsheet, May 2007, Paris: OECD.

Paldam, Martin and Peter Sandholt Jensen. 2006. Can the New Aid-Growth Models be Replicated? Public Choice, vol. 127 (1-2), 147-175.

Perotti, Enrico C. 1998. Inertial Credit and Opportunistic Arrears in Transition. European Economic Review, vol. 42, 1703-25.

Potrafke, Niklas. 2009. Does Government Ideology Influence Political Alignment with the U.S.? An Empirical Analysis of Voting in the UN General Assembly. Review of International Organizations, vol. 4, $245-268$.

Rajan, Raghuram R. and Arvind Subramanian. 2008. Aid and Growth: What Does the Cross-Country Evidence Really Show? Review of Economics and Statistics, vol. 90, 643-665. 
Rajan, Raghuram R. and Arvind Subramanian. In press. Aid, Dutch Disease, and Manufacturing Growth. Forthcoming in Journal of Development Economics.

Reinhart, Carmen M. and Kenneth S. Rogoff. 2009. This Time is Different: Eight Centuries of Financial Folly. Princeton University Press: Princeton, NJ.

Remmer, Karen. 2004. Does Foreign Aid Promote the Expansion of Government? American Journal of Political Science, vol. 48, 77-92.

Tornell, Aaron and Philip R. Lane. 1999. The Voracity Effect. American Economic Review, vol. 89, 22-46.

Voeten, Erik. 2004. Documenting Votes in the UN General Assembly. Department of Political Science and International Affairs, George Washington University; available at http://home.gwu.edu/ voeten/UNVoting.htm (accessed April 2009).

Vreeland, James Raymond. 2008. The Effect of Political Regime on Civil War: Unpacking Anocracy. Journal of Conflict Resolution 52, 401-425.

World Bank. 2010. World Development Indicators. Online database, the World Bank: Washington DC. 
Table 1. Descriptive statistics

\begin{tabular}{|c|c|c|c|c|c|}
\hline & Mean & Minimum & Maximum & $\begin{array}{l}\text { Standard } \\
\text { deviation }\end{array}$ & Observations \\
\hline Aid, $\%$ of GNI & 9.042 & -.053 & 59.733 & 9.968 & 570 \\
\hline External debt, \% of GNI & 79.506 & .829 & 703.028 & 82.934 & 527 \\
\hline Total debt service, $\%$ of GNI & 5.456 & .011 & 41.598 & 4.547 & 506 \\
\hline $\begin{array}{l}\text { Debt service, guaranteed } \\
\text { debt, } \% \text { of GNI }\end{array}$ & 3.924 & .000 & 24.875 & 3.394 & 506 \\
\hline Short term debt & 12.362 & 0 & 70.129 & 10.847 & 507 \\
\hline Guaranteed debt, $\%$ of GNI & 75.420 & .829 & 703.028 & 82.819 & 531 \\
\hline Non-guaranteed debt share & .065 & 0 & .806 & .121 & 533 \\
\hline Log GNI per capita & 7.415 & 5.328 & 9.185 & .931 & 575 \\
\hline Trade, \% of GDP & 74.238 & 11.44 & 241.024 & 39.895 & 567 \\
\hline Voting with the US & .209 & .016 & .521 & .118 & 538 \\
\hline UNSC member & .310 & 0 & 2 & .668 & 561 \\
\hline Exchange rate appreciation & .143 & -.100 & 3.439 & .336 & 574 \\
\hline Democracy & .405 & 0 & 1 & .419 & 570 \\
\hline HIPC country & .118 & 0 & 1 & .323 & 575 \\
\hline Baker / Brady plan & .067 & 0 & 1 & .251 & 536 \\
\hline Coups, successful & .120 & 0 & 3 & .398 & 575 \\
\hline Coups, attempted & .419 & 0 & 6 & .903 & 575 \\
\hline Log population & 15.399 & 10.631 & 20.785 & 2.027 & 575 \\
\hline Life expectancy & 60.094 & 28.197 & 78.329 & 9.599 & 570 \\
\hline Russian friend & .638 & 0 & 1 & .481 & 538 \\
\hline Xpolity & .797 & -6 & 7 & 4.447 & 506 \\
\hline
\end{tabular}


Table 2. Main results, Random effect

\begin{tabular}{|c|c|c|c|c|c|c|}
\hline & \multicolumn{3}{|c|}{ Total debt service, $\%$ of GNI } & \multicolumn{3}{|c|}{ Service on guaranteed debt, $\%$ of GNI } \\
\hline & $\mathrm{GNI}<10,000$ & GNI $<7000$ & GNI $<5000$ & $\mathrm{GNI}<10,000$ & GNI $<7000$ & GNI $<5000$ \\
\hline Aid, $\%$ of GNI & $\begin{array}{c}.280^{* * *} \\
(.074)\end{array}$ & $\begin{array}{c}-.280 * * * \\
(.078)\end{array}$ & $\begin{array}{c}-.301 * * * \\
(.085)\end{array}$ & $\begin{array}{c}.254^{* * *} \\
(.072)\end{array}$ & $\begin{array}{c}-.263 * * * \\
(.081)\end{array}$ & $\begin{array}{c}-.287 * * * \\
(.090)\end{array}$ \\
\hline $\begin{array}{l}\text { Total external debt, } \% \text { of } \\
\text { GNI }\end{array}$ & $\begin{array}{c}.037 * * * \\
(.011)\end{array}$ & $\begin{array}{c}.037 * * * \\
(.011)\end{array}$ & $\begin{array}{c}.037 * * * \\
(.011)\end{array}$ & & & \\
\hline $\begin{array}{l}\text { Publically guaranteed } \\
\text { debt, } \% \text { of GNI }\end{array}$ & & & & $\begin{array}{l}.028^{* * *} \\
(.007)\end{array}$ & $\begin{array}{l}.028^{* * *} \\
(.007)\end{array}$ & $\begin{array}{l}.028^{* * *} \\
(.007)\end{array}$ \\
\hline GNI per capita, 1000 & -.192 & -.292 & -.259 & -.108 & -.183 & -.168 \\
\hline USD & $(.239)$ & $(.355)$ & $(.488)$ & $(.215)$ & $(.331)$ & $(.481)$ \\
\hline Trade, $\%$ of GDP & $\begin{array}{l}.036 * * * \\
(.013)\end{array}$ & $\begin{array}{c}.040 * * * \\
(.014)\end{array}$ & $\begin{array}{c}.043^{* * *} \\
(.014)\end{array}$ & $\begin{array}{c}.029 * * * \\
(.010)\end{array}$ & $\begin{array}{c}.033^{* * *} \\
(.012)\end{array}$ & $\begin{array}{c}.036^{* * *} \\
(.012)\end{array}$ \\
\hline FDI, $\%$ of GDP & $\begin{array}{l}-.119 \\
(.148)\end{array}$ & $\begin{array}{l}-.145 \\
(.151)\end{array}$ & $\begin{array}{l}-.165 \\
(.154)\end{array}$ & $\begin{array}{l}-.047 \\
(.118)\end{array}$ & $\begin{array}{l}-.067 \\
(.115)\end{array}$ & $\begin{array}{l}-.084 \\
(.114)\end{array}$ \\
\hline $\begin{array}{l}\text { Exchange rate } \\
\text { appreciation }\end{array}$ & $\begin{array}{l}-1.961 \\
(1.528)\end{array}$ & $\begin{array}{l}-1.944 \\
(1.587)\end{array}$ & $\begin{array}{l}-2.169 \\
(1.743)\end{array}$ & $\begin{array}{l}-1.457 \\
(1.174)\end{array}$ & $\begin{array}{l}-1.539 \\
(1.217)\end{array}$ & \\
\hline Voting with the US & $\begin{array}{l}9.982^{* *} \\
(4.080)\end{array}$ & $\begin{array}{c}10.589 * * * \\
(4.064)\end{array}$ & $\begin{array}{c}12.536^{* * *} \\
(4.402)\end{array}$ & $\begin{array}{l}8.639 * * \\
(3.523)\end{array}$ & $\begin{array}{l}9.363^{* *} \\
(3.676)\end{array}$ & $\begin{array}{c}11.188^{* * *} \\
(3.963)\end{array}$ \\
\hline UNSC member & $\begin{array}{l}.364^{*} \\
(.197)\end{array}$ & $\begin{array}{l}.497 * * \\
(.204)\end{array}$ & $\begin{array}{l}.528^{* *} \\
(.225)\end{array}$ & $\begin{array}{l}.325^{*} \\
(.168)\end{array}$ & $\begin{array}{l}.439 * * \\
(.179)\end{array}$ & $\begin{array}{l}.470^{* *} \\
(.199)\end{array}$ \\
\hline HIPC country & $\begin{array}{c}-1.647 * * \\
(.744)\end{array}$ & $\begin{array}{c}-1.480^{* *} \\
(.745)\end{array}$ & $\begin{array}{l}-.986 \\
(.805)\end{array}$ & $\begin{array}{c}-1.323^{* *} \\
(.594)\end{array}$ & $\begin{array}{c}-1.231 * * \\
(.603)\end{array}$ & $\begin{array}{l}-.784 \\
(.665)\end{array}$ \\
\hline Baker / Brady plan & $\begin{array}{l}.052 \\
(.533)\end{array}$ & $\begin{array}{l}.145 \\
(.637)\end{array}$ & $\begin{array}{r}.177 \\
(.650)\end{array}$ & $\begin{array}{l}-.037 \\
(.463)\end{array}$ & $\begin{array}{l}-.045 \\
(.529)\end{array}$ & $\begin{array}{l}.084 \\
(.526)\end{array}$ \\
\hline Coups, attempts & $\begin{array}{l}-.110 \\
(.194)\end{array}$ & $\begin{array}{l}-.113 \\
(.198)\end{array}$ & $\begin{array}{l}-.115 \\
(.201)\end{array}$ & $\begin{array}{l}-.105 \\
(.155)\end{array}$ & $\begin{array}{l}-.100 \\
(.159)\end{array}$ & $\begin{array}{l}-.098 \\
(.159)\end{array}$ \\
\hline Democracy & $\begin{array}{l}-.069 \\
(.469)\end{array}$ & $\begin{array}{l}-.166 \\
(.474)\end{array}$ & $\begin{array}{l}-.182 \\
(.503)\end{array}$ & $\begin{array}{l}-.012 \\
(.361)\end{array}$ & $\begin{array}{l}-.082 \\
(.370)\end{array}$ & $\begin{array}{l}-.099 \\
(.392)\end{array}$ \\
\hline $\begin{array}{l}\text { Short-term debt, } \% \text { of } \\
\text { total }\end{array}$ & $\begin{array}{c}-.085^{* *} \\
(.034)\end{array}$ & $\begin{array}{c}-.081 * * \\
(.037)\end{array}$ & $\begin{array}{c}-.086^{* *} \\
(.042)\end{array}$ & $\begin{array}{c}-.079 * * * \\
(.029)\end{array}$ & $\begin{array}{c}-.078^{* *} \\
(.032)\end{array}$ & $\begin{array}{c}-.079 * * \\
(.034)\end{array}$ \\
\hline $\begin{array}{l}\text { Non-guaranteed debt, \% } \\
\text { of total }\end{array}$ & $\begin{array}{l}8.059 * * * \\
(2.129)\end{array}$ & $\begin{array}{l}9.774^{* * *} \\
(1.941)\end{array}$ & $\begin{array}{c}10.482^{* * *} \\
(2.190)\end{array}$ & $\begin{array}{c}.501 \\
(1.389)\end{array}$ & $\begin{array}{c}1.481 \\
(1.189)\end{array}$ & $\begin{array}{c}2.012 \\
(1.399)\end{array}$ \\
\hline Observations & 487 & 460 & 418 & 487 & 460 & 418 \\
\hline Countries & 93 & 92 & 89 & 93 & 92 & 89 \\
\hline Within R squared & .199 & .201 & .202 & .165 & .165 & .176 \\
\hline Between R squared & .586 & .602 & .582 & .533 & .535 & .498 \\
\hline Wald Chi squared / F stat & 9.72 & 12.14 & 15.02 & 6.06 & 7.22 & 8.87 \\
\hline Hansen J statistic, $\mathrm{p}<$ & .634 & .458 & .338 & .623 & .373 & .228 \\
\hline
\end{tabular}

Note: $* * *(* *)[*]$ denotes significance at $\mathrm{p}<.01(\mathrm{p}<.05)[\mathrm{p}<.10]$. All regressions include dummies for Latin American and the Caribbean, Asia, Sub-Saharan Africa and the Middle East and North Africa. Instruments for aid are the logarithm to population size, life expectancy at birth, and democracy. 
Table 3. Main results, alternative indicators

\begin{tabular}{|c|c|c|c|c|c|c|}
\hline & \multicolumn{3}{|c|}{ Total debt service, $\%$ of GNI } & \multicolumn{3}{|c|}{ Service on guaranteed debt, $\%$ of GNI } \\
\hline & 1 & 2 & 3 & 4 & 5 & 6 \\
\hline Aid, $\%$ of GNI & $\begin{array}{c}-.272 * * * \\
(.083)\end{array}$ & $\begin{array}{c}-.279 * * * \\
(.074)\end{array}$ & $\begin{array}{c}-.283 * * * \\
(.081)\end{array}$ & $\begin{array}{c}-.246 * * * \\
(.078)\end{array}$ & $\begin{array}{c}-.254 * * * \\
(.072)\end{array}$ & $\begin{array}{c}-.267 * * * \\
(.075)\end{array}$ \\
\hline $\begin{array}{l}\text { Total external debt, } \% \text { of } \\
\text { GNI }\end{array}$ & $\begin{array}{c}.037 * * * \\
(.011)\end{array}$ & $\begin{array}{c}.037 * * * \\
(.011)\end{array}$ & $\begin{array}{l}.036^{* * *} \\
(.012)\end{array}$ & & & \\
\hline $\begin{array}{l}\text { Publically guaranteed } \\
\text { debt, } \% \text { of GNI }\end{array}$ & & & & $\begin{array}{c}.028 * * * \\
(.007)\end{array}$ & $\begin{array}{c}.028 * * * \\
(.007)\end{array}$ & $\begin{array}{c}.027 * * * \\
(.007)\end{array}$ \\
\hline $\begin{array}{l}\text { GNI per capita, } 1000 \\
\text { USD }\end{array}$ & $\begin{array}{l}-.189 \\
(.242)\end{array}$ & $\begin{array}{l}-.189 \\
(.239)\end{array}$ & $\begin{array}{l}-.337 \\
(.249)\end{array}$ & $\begin{array}{l}-.107 \\
(.217)\end{array}$ & $\begin{array}{l}-.103 \\
(.217)\end{array}$ & $\begin{array}{l}-.246 \\
(.217)\end{array}$ \\
\hline Trade, $\%$ of GDP & $\begin{array}{l}.036 * * * \\
(.013)\end{array}$ & $\begin{array}{l}.036 * * * \\
(.013)\end{array}$ & $\begin{array}{l}.041 * * * \\
(.014)\end{array}$ & $\begin{array}{c}.029 * * * \\
(.010)\end{array}$ & $\begin{array}{l}.029 * * * \\
(.010)\end{array}$ & $\begin{array}{c}.035^{* * *} \\
(.011)\end{array}$ \\
\hline FDI, $\%$ of GDP & $\begin{array}{l}-.112 \\
(.139)\end{array}$ & $\begin{array}{l}-.120 \\
(.146)\end{array}$ & $\begin{array}{l}-.147 \\
(.154)\end{array}$ & $\begin{array}{l}-.039 \\
(.113)\end{array}$ & $\begin{array}{l}-.047 \\
(.117)\end{array}$ & $\begin{array}{l}-.065 \\
(.117)\end{array}$ \\
\hline $\begin{array}{l}\text { Exchange rate } \\
\text { appreciation }\end{array}$ & $\begin{array}{l}-1.981 \\
(1.509)\end{array}$ & $\begin{array}{l}-1.966 \\
(1.527)\end{array}$ & & $\begin{array}{l}-1.478 \\
(1.160)\end{array}$ & $\begin{array}{l}-1.452 \\
(1.173)\end{array}$ & \\
\hline Voting with the US & $\begin{array}{c}7.717 \\
(6.515)\end{array}$ & $\begin{array}{l}9.813^{* *} \\
(4.086)\end{array}$ & $\begin{array}{c}10.378^{* *} \\
(4.915)\end{array}$ & $\begin{array}{c}6.357 \\
(5.762)\end{array}$ & $\begin{array}{l}8.482^{* *} \\
(3.530)\end{array}$ & $\begin{array}{l}9.243^{* *} \\
(4.206)\end{array}$ \\
\hline UNSC member & $\begin{array}{l}.353^{*} \\
(.203)\end{array}$ & $\begin{array}{l}.364 * \\
(.197)\end{array}$ & $\begin{array}{l}.387^{*} \\
(.205)\end{array}$ & $\begin{array}{l}.314^{*} \\
(.171)\end{array}$ & $\begin{array}{l}.323^{*} \\
(.167)\end{array}$ & $\begin{array}{l}.343 * * \\
(.173)\end{array}$ \\
\hline HIPC country & $\begin{array}{c}-1.577 * * \\
(.756)\end{array}$ & $\begin{array}{c}-1.629 * * \\
(.736)\end{array}$ & $\begin{array}{c}-1.642^{*} \\
(.832)\end{array}$ & $\begin{array}{c}-1.250^{* *} \\
(.616)\end{array}$ & $\begin{array}{c}-1.308^{* *} \\
(.591)\end{array}$ & $\begin{array}{c}-1.234^{*} \\
(.638)\end{array}$ \\
\hline Baker / Brady plan & $\begin{array}{l}.091 \\
(.541)\end{array}$ & $\begin{array}{l}.045 \\
(.532)\end{array}$ & $\begin{array}{l}-.021 \\
(.533)\end{array}$ & $\begin{array}{l}.001 \\
(.471)\end{array}$ & $\begin{array}{l}-.037 \\
(.457)\end{array}$ & $\begin{array}{l}-.125 \\
(.437)\end{array}$ \\
\hline Coups, attempts & $\begin{array}{l}-.103 \\
(.194)\end{array}$ & & $\begin{array}{l}-.119 \\
(.189)\end{array}$ & $\begin{array}{l}-.098 \\
(.154)\end{array}$ & & $\begin{array}{l}-.112 \\
(.155)\end{array}$ \\
\hline Democracy & $\begin{array}{l}-.064 \\
(.479)\end{array}$ & $\begin{array}{l}-.095 \\
(.465)\end{array}$ & & $\begin{array}{l}-.006 \\
(.365)\end{array}$ & $\begin{array}{l}-.013 \\
(.354)\end{array}$ & \\
\hline $\begin{array}{l}\text { Short-term debt, } \% \text { of } \\
\text { total }\end{array}$ & $\begin{array}{c}-.084 * * \\
(.033)\end{array}$ & $\begin{array}{c}-.085^{* *} \\
(.034)\end{array}$ & $\begin{array}{c}-.081 * * \\
(.036)\end{array}$ & $\begin{array}{c}-.079 * * * \\
(.028)\end{array}$ & $\begin{array}{c}-.079 * * * \\
(.029)\end{array}$ & $\begin{array}{c}-.076^{* * *} \\
(.029)\end{array}$ \\
\hline $\begin{array}{l}\text { Non-guaranteed debt, } \% \\
\text { of total }\end{array}$ & $\begin{array}{c}8.091 * * * \\
(2.160)\end{array}$ & $\begin{array}{c}8.099 * * * \\
(2.119)\end{array}$ & $\begin{array}{l}8.085^{* * *} \\
(2.140)\end{array}$ & $\begin{array}{c}.510 \\
(1.409)\end{array}$ & $\begin{array}{c}.553 \\
(1.382)\end{array}$ & $\begin{array}{c}.563 \\
(1.423)\end{array}$ \\
\hline Voting with Russia & $\begin{array}{l}1.261 \\
(2.511)\end{array}$ & & & $\begin{array}{l}1.276 \\
(1.927)\end{array}$ & & \\
\hline Coups, successful & & $\begin{array}{l}-.253 \\
(.324)\end{array}$ & & & $\begin{array}{l}-.099 \\
(.273)\end{array}$ & \\
\hline Xpolity & & & $\begin{array}{l}.003 \\
(.075)\end{array}$ & & & $\begin{array}{l}-.015 \\
(.047)\end{array}$ \\
\hline Observations & 487 & 487 & 452 & 487 & 487 & 452 \\
\hline Countries & 93 & 93 & 84 & 93 & 93 & 84 \\
\hline Within R squared & .202 & .199 & .203 & .169 & .164 & .165 \\
\hline Between R squared & .594 & .586 & .595 & .542 & .532 & .528 \\
\hline Wald Chi squared / F stat & 9.53 & 9.46 & 9.15 & 6.25 & 6.01 & 6.14 \\
\hline Hansen $\mathrm{J}$ statistic, $\mathrm{p}<$ & .681 & .653 & .326 & .675 & .657 & .278 \\
\hline
\end{tabular}

Note: ${ }^{* * *}(* *)\left[{ }^{*}\right]$ denotes significance at $\mathrm{p}<.01(\mathrm{p}<.05)[\mathrm{p}<.10]$. All regressions include dummies for Latin American and the Caribbean, Asia, Sub-Saharan Africa and the Middle East and North Africa. Instruments for aid are the logarithm to population size, life expectancy at birth, and democracy. 
Table 4. Main results, robustness to exclusion of tail observations

\begin{tabular}{|c|c|c|c|c|c|c|}
\hline & \multicolumn{3}{|c|}{ Total debt service, $\%$ of GNI } & \multicolumn{3}{|c|}{ Service on guaranteed debt, $\%$ of GNI } \\
\hline & 1 & 2 & 3 & 5 & 6 & 7 \\
\hline Aid, $\%$ of GNI & $\begin{array}{c}-.393^{* *} \\
(.160)\end{array}$ & $\begin{array}{c}-.257 * * * \\
(.068)\end{array}$ & $\begin{array}{c}-.208^{* *} \\
(.083)\end{array}$ & $\begin{array}{l}-382^{* * *} \\
(.127)\end{array}$ & $\begin{array}{c}-.212 * * * \\
(.055)\end{array}$ & $\begin{array}{c}-167 * * * \\
(.049)\end{array}$ \\
\hline $\begin{array}{l}\text { Total external debt, } \% \text { of } \\
\text { GNI }\end{array}$ & $\begin{array}{l}.049 * * * \\
(.015)\end{array}$ & $\begin{array}{c}.071 * * * \\
(.008)\end{array}$ & $\begin{array}{l}.029 * * * \\
(.009)\end{array}$ & & & \\
\hline $\begin{array}{l}\text { Publically guaranteed } \\
\text { debt, } \% \text { of GNI }\end{array}$ & & & & $\begin{array}{l}.032 * * * \\
(.007)\end{array}$ & $\begin{array}{l}.054 * * * \\
(.007)\end{array}$ & $\begin{array}{l}.021 * * * \\
(.007)\end{array}$ \\
\hline GNI per capita, 1000 & -.081 & .187 & .018 & -.045 & .202 & -.099 \\
\hline USD & $(.361)$ & $(.166)$ & $(.205)$ & $(.313)$ & $(.147)$ & $(.135)$ \\
\hline Trade, $\%$ of GDP & $\begin{array}{l}.031 * * \\
(.012)\end{array}$ & $\begin{array}{l}.021 * * * \\
(.008)\end{array}$ & $\begin{array}{l}.013 \\
(.009)\end{array}$ & $\begin{array}{l}.028^{* *} \\
(.011)\end{array}$ & $\begin{array}{l}.018^{* * *} \\
(.006)\end{array}$ & $\begin{array}{l}.012^{* *} \\
(.006)\end{array}$ \\
\hline FDI, $\%$ of GDP & $\begin{array}{l}-.052 \\
(.129)\end{array}$ & $\begin{array}{l}.033 \\
(.069)\end{array}$ & $\begin{array}{l}-.079 \\
(.065)\end{array}$ & $\begin{array}{l}-.005 \\
(.102)\end{array}$ & $\begin{array}{l}.039 \\
(.058)\end{array}$ & $\begin{array}{l}-.044 \\
(.048)\end{array}$ \\
\hline $\begin{array}{l}\text { Exchange rate } \\
\text { appreciation }\end{array}$ & $\begin{array}{l}-3.611 * \\
(2.053)\end{array}$ & $\begin{array}{l}-.465 \\
(.652)\end{array}$ & $\begin{array}{l}-2.046^{*} \\
(1.134)\end{array}$ & $\begin{array}{l}-2.304^{*} \\
(1.235)\end{array}$ & $\begin{array}{l}-.244 \\
(.597)\end{array}$ & $\begin{array}{c}-1.468^{*} \\
(.869)\end{array}$ \\
\hline Voting with the US & $\begin{array}{l}8.878^{* *} \\
(4.370)\end{array}$ & $\begin{array}{l}9.270 * * * \\
(2.869)\end{array}$ & $\begin{array}{l}8.041 * * * \\
(2.923)\end{array}$ & $\begin{array}{l}7.542^{* *} \\
(3.686)\end{array}$ & $\begin{array}{l}6.565^{* *} \\
(2.889)\end{array}$ & $\begin{array}{l}5.887^{* *} \\
(2.217)\end{array}$ \\
\hline UNSC member & $\begin{array}{l}.642^{* * *} \\
(.219)\end{array}$ & $\begin{array}{l}.446^{* *} \\
(.198)\end{array}$ & $\begin{array}{l}.134 \\
(.178)\end{array}$ & $\begin{array}{l}.508^{* *} \\
(.198)\end{array}$ & $\begin{array}{l}.408^{* *} \\
(.177)\end{array}$ & $\begin{array}{l}.139 \\
(.119)\end{array}$ \\
\hline HIPC country & $\begin{array}{l}-1.432 \\
(.921)\end{array}$ & $\begin{array}{c}-1.287 * * \\
(.526)\end{array}$ & $\begin{array}{l}-.479 \\
(.709)\end{array}$ & $\begin{array}{l}-1.032 \\
(.713)\end{array}$ & $\begin{array}{c}-1.398^{* * *} \\
(.471)\end{array}$ & $\begin{array}{l}-.703 \\
(.467)\end{array}$ \\
\hline Baker / Brady plan & $\begin{array}{l}.091 \\
(.866)\end{array}$ & $\begin{array}{l}-.461 \\
(.505)\end{array}$ & $\begin{array}{c}.418 \\
(1.001)\end{array}$ & $\begin{array}{l}.052 \\
(.676)\end{array}$ & $\begin{array}{l}-.475 \\
(.446)\end{array}$ & $\begin{array}{l}.145 \\
(.474)\end{array}$ \\
\hline Coups, attempts & $\begin{array}{l}-.144 \\
(.171)\end{array}$ & $\begin{array}{l}-.262 \\
(.159)\end{array}$ & $\begin{array}{l}.072 \\
(.151)\end{array}$ & $\begin{array}{l}-.142 \\
(.134)\end{array}$ & $\begin{array}{l}-.169 \\
(.132)\end{array}$ & $\begin{array}{l}.029 \\
(.113)\end{array}$ \\
\hline Democracy & $\begin{array}{l}-.188 \\
(.622)\end{array}$ & $\begin{array}{l}.046 \\
(.381)\end{array}$ & $\begin{array}{l}.079 \\
(.442)\end{array}$ & $\begin{array}{l}-.200 \\
(.408)\end{array}$ & $\begin{array}{l}-.132 \\
(.310)\end{array}$ & $\begin{array}{l}.011 \\
(.306)\end{array}$ \\
\hline $\begin{array}{l}\text { Short-term debt, } \% \text { of } \\
\text { total }\end{array}$ & $\begin{array}{c}-.109 * * * \\
(.033)\end{array}$ & $\begin{array}{c}-.092^{* * *} \\
(.021)\end{array}$ & $\begin{array}{c}-.056^{* * * *} \\
(.017)\end{array}$ & $\begin{array}{c}-.105^{* * * *} \\
(.023)\end{array}$ & $\begin{array}{c}-.081 * * * \\
(.024)\end{array}$ & $\begin{array}{c}-.037 * * \\
(.014)\end{array}$ \\
\hline $\begin{array}{l}\text { Non-guaranteed debt, } \% \\
\text { of total }\end{array}$ & $\begin{array}{l}9.191 * * \\
(3.791)\end{array}$ & $\begin{array}{l}7.236 * * * \\
(2.345)\end{array}$ & $\begin{array}{c}5.835^{* * *} \\
(1.918)\end{array}$ & $\begin{array}{c}1.277 \\
(2.456)\end{array}$ & $\begin{array}{c}1.784 \\
(1.454)\end{array}$ & $\begin{array}{l}.685 \\
(1.139)\end{array}$ \\
\hline Observations & 387 & 387 & 387 & 387 & 387 & 387 \\
\hline Countries & 86 & 91 & 91 & 86 & 91 & 91 \\
\hline Within R squared & .289 & .442 & .149 & .191 & .321 & .081 \\
\hline Between R squared & .669 & .641 & .499 & .592 & .597 & .386 \\
\hline Wald Chi squared / F stat & 10.93 & 11.69 & 7.35 & 11.31 & 8.79 & 3.31 \\
\hline Hansen J statistic, $\mathrm{p}<$ & .334 & .179 & .730 & .444 & .482 & .581 \\
\hline
\end{tabular}

Note: $* * *(* *)[*]$ denotes significance at $\mathrm{p}<.01(\mathrm{p}<.05)[\mathrm{p}<.10]$. All regressions include dummies for Latin American and the Caribbean, Asia, Sub-Saharan Africa and the Middle East and North Africa. Instruments for aid are the logarithm to population size, life expectancy at birth, and democracy. Ten percent tails for the aid distribution are $>21$ percent and $<.3$ percent; for the distribution of total debts, $<155$ percent and $>24$ percent; for the distribution of total debt service, $<10.9$ percent and $>1.1$ percent; for the distribution of service on guaranteed debt, $<154$ percent and $>22$ percent; and for the distribution of total debt service, $<7.7$ percent and $>.8$ percent. 
Table 5. Interaction results

\begin{tabular}{|c|c|c|c|c|c|c|c|c|c|c|}
\hline \multirow[b]{2}{*}{ Interaction with } & \multicolumn{5}{|c|}{ Total debt service, $\%$ of GNI } & \multicolumn{5}{|c|}{ Service on guaranteed debt, $\%$ of GNI } \\
\hline & $\begin{array}{l}\text { Coups, } \\
\text { attempted }\end{array}$ & Democracy & Xpolity & $\begin{array}{l}\text { Exchange } \\
\text { rate app. }\end{array}$ & US vote & $\begin{array}{l}\text { Coups, } \\
\text { attempted }\end{array}$ & Democracy & Xpolity & $\begin{array}{l}\text { Exchange } \\
\text { rate app. }\end{array}$ & US vote \\
\hline \multirow[t]{2}{*}{ Aid, $\%$ of GNI } & $-.277 * * *$ & $-.250 * * *$ & $-.277 * * *$ & $-.296^{* * *}$ & $-.351 * *$ & $-.247 * * *$ & $-.239 * * *$ & $-.245^{* * *}$ & $-.259 * * *$ & $-.328^{*}$ \\
\hline & $(.077)$ & $(.093)$ & $(.096)$ & $(.096)$ & $(.162)$ & $(.072)$ & $(.082)$ & $(.0759$ & $(.084)$ & $(.170)$ \\
\hline \multirow[t]{2}{*}{ Additional variable } & -.021 & -.094 & .129 & -2.162 & 8.086 & .019 & .423 & .048 & -1.361 & 7.507 \\
\hline & $(.348)$ & $(.195)$ & $(.153)$ & $(1.609)$ & $(5.957)$ & $(.319)$ & $(.850)$ & $(.092)$ & $(1.205)$ & $(6.096)$ \\
\hline \multirow[t]{2}{*}{ Interaction } & -.008 & -.083 & -.011 & .025 & .296 & -.011 & -.045 & -.005 & -.021 & .265 \\
\hline & $(.029)$ & $(.119)$ & $(.020)$ & $(.554)$ & $(.311)$ & $(.026)$ & $(.095)$ & $(.012)$ & $(.376)$ & $(.282)$ \\
\hline Observations & 487 & 487 & 441 & 487 & 487 & 487 & 487 & 441 & 487 & 487 \\
\hline Countries & 93 & 93 & 82 & 93 & 93 & 93 & 93 & 82 & 93 & 93 \\
\hline Within R squared & .198 & .197 & .221 & .195 & .193 & .163 & .159 & .192 & .162 & .156 \\
\hline Between R squared & .584 & .591 & .620 & .571 & .566 & .533 & .535 & .587 & .523 & .501 \\
\hline Wald Chi squared / F stat & 10.14 & 9.94 & 10.68 & 8.61 & 9.42 & 6.18 & 5.79 & 8.26 & 6.21 & 5.09 \\
\hline Hansen $\mathrm{J}$ statistic, $\mathrm{p}<$ & .625 & .780 & .643 & .653 & .688 & .612 & .705 & .542 & .582 & .606 \\
\hline \multicolumn{11}{|l|}{ Interaction evaluated at: } \\
\hline \multirow[t]{2}{*}{ Minimum } & $-.277 * * *$ & $-.250 * * *$ & -.213 & $-.299 * *$ & $-.346 * *$ & $-.247 * * *$ & $-.239 * * *$ & $-.216^{*}$ & $-.257 * *$ & $-.324 *$ \\
\hline & $(.077)$ & $(.093)$ & $(.156)$ & $(.139)$ & $(.162)$ & $(.072)$ & $(.082)$ & $(.125)$ & $(.108)$ & $(.168)$ \\
\hline \multirow[t]{2}{*}{ Maximum } & $-.325^{*}$ & $-.334 * * *$ & $-.352^{* *}$ & -.209 & -.196 & $-.316^{*}$ & $-.285^{* * *}$ & $-.279 * * *$ & -.333 & -.190 \\
\hline & $(.173)$ & $(.102)$ & $(.170)$ & $(1.851)$ & $(.219)$ & $(.167)$ & $(.093)$ & $(.087)$ & $(1.258)$ & $(.177)$ \\
\hline
\end{tabular}

Note: $* * *(* *)[*]$ denotes significance at $\mathrm{p}<.01(\mathrm{p}<.05)[\mathrm{p}<.10]$. All regressions include the full baseline specification. Instruments for aid are the log to population and life expectancy at birth. Instruments for interactions are interactions between the interacting variable and life expectancy / log population. The maximum (minimum) number of successful coups in the sample is three (zero), the maximum (minimum) number of attempted coups is six (zero), the maximum (minimum) score for Xpolity is 7 (-6), the maximum (minimum) annual exchange rate appreciation is 3.43 (-.11) percent, and the maximum (minimum) vote with the US is .52 (.02). 
Figure 1: The lending game (payoffs: A, B)

\begin{tabular}{|c|c|c|c|}
\hline \multirow[b]{3}{*}{ Country A } & \multirow[b]{3}{*}{$\begin{array}{l}\text { Commit, pay fast } \\
\text { Do not commit, pay slowly }\end{array}$} & \multicolumn{2}{|c|}{ Bank B } \\
\hline & & Lend money & Do not lend money \\
\hline & & $\begin{array}{l}\beta-\tau, a \\
\beta, a-\sigma\end{array}$ & $\begin{array}{c}u-\tau, 0 \\
u, 0\end{array}$ \\
\hline
\end{tabular}


Figure 2. Aid and debt service, 1980-2005

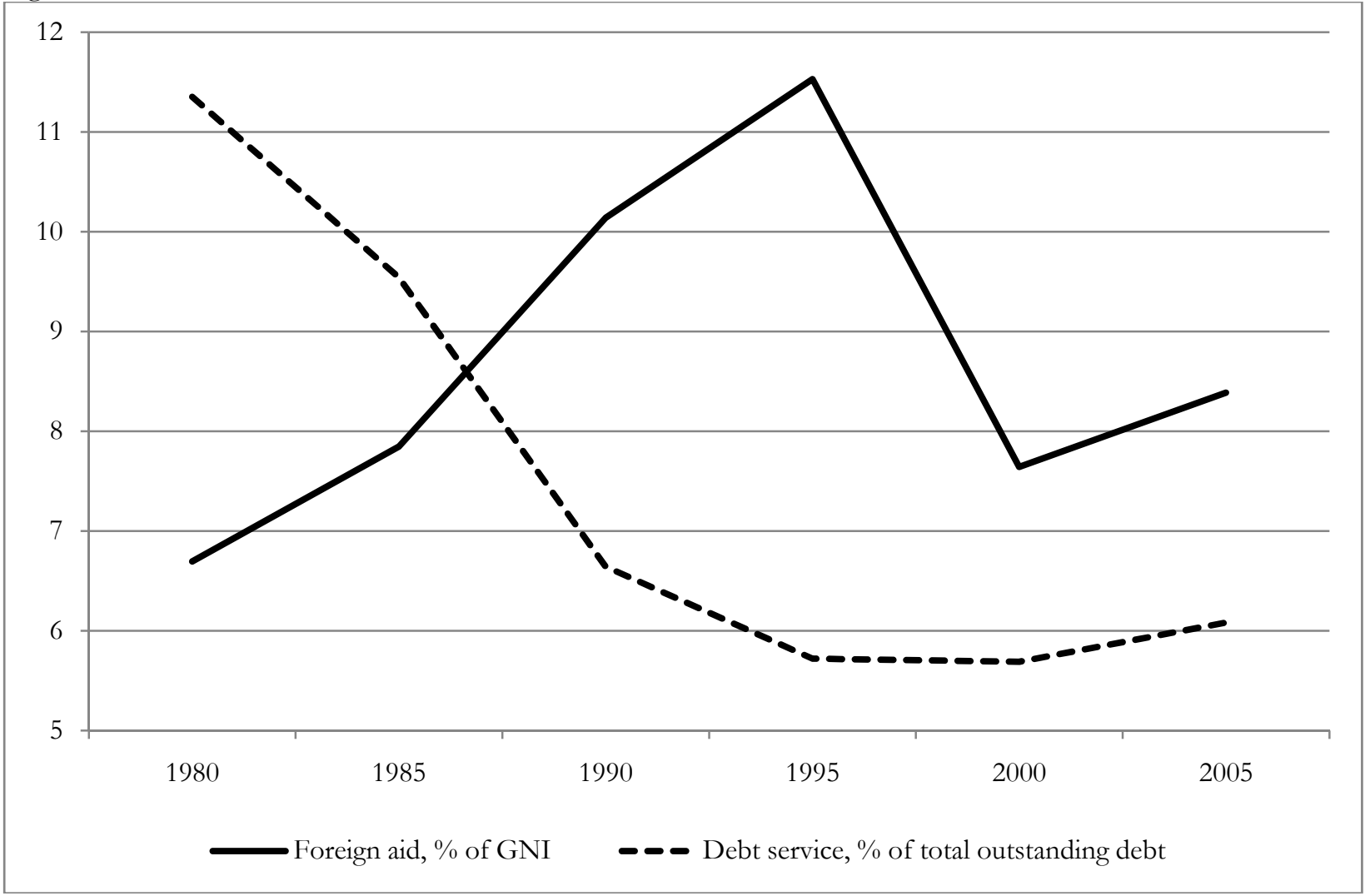


Department of Economics:

Skriftserie/Working Paper:

2009:

WP 09-1 Tomi Kyyrä, Pierpaolo Parrotta and Michael Rosholm: The Effect of Receiving Supplementary UI Benefits on Unemployment Duration ISBN 9788778824035 (print); ISBN 9788778824042 (online)

WP 09-2 Dario Pozzoli and Marco Ranzani: Old European Couples' Retirement Decisions: the Role of Love and Money ISBN 9788778824165 (print); ISBN 9788778824172 (online)

WP 09-3 Michael Gibbs, Mikel Tapia and Frederic Warzynski: Globalization, Superstars, and the Importance of Reputation: Theory \& Evidence from the Wine Industry ISBN 9788778824189 (print); ISBN 9788778824196 (online)

WP 09-4 Jan De Loecker and Frederic Warzynski: Markups and FirmLevel Export Status ISBN 9788778824202 (print); ISBN 9788778824219 (online)

WP 09-5 Tor Eriksson, Mariola Pytliková and Frédéric Warzynski: Increased Sorting and Wage Inequality in the Czech Republic: New Evidence Using Linked Employer-Employee Dataset ISBN 9788778824226 (print); ISBN 9788778824233 (online)

WP 09-6 Longhwa Chen and Tor Eriksson: Vacancy Duration, Wage Offers, and Job Requirements - Pre-Match Data Evidence ISBN 9788778824240 (print); ISBN 9788778824257 (online)

WP 09-7 Tor Eriksson, Valérie Smeets and Frédéric Warzynski: Small Open Economy Firms in International Trade: Evidence from Danish Transactions-Level Data ISBN 9788778823861 (print); ISBN 9788778823878 (online)

WP 09-8 Dario Pozzoli and Marco Ranzani: Participation and Sector Selection in Nicaragua ISBN 9788778823885 (print); ISBN 9788778823892 (online) 
WP 09-9 Rikke Ibsen, Frederic Warzynski and Niels Westergård-Nielsen: Employment Growth and International Trade: A Small Open Economy Perspective ISBN 9788778823908 (print); ISBN 9788778823915 (online)

WP 09-10 Roger Bandick and Holger Görg: Foreign acquisition, plant survival, and employment growth ISBN 9788778823922 (print); ISBN 9788778823939 (online)

WP 09-11 Pierpaolo Parrotta and Dario Pozzoli: The Effect of Learning by Hiring on Productivity

ISBN 9788778823946 (print); ISBN 9788778823953 (online)

WP 09-12 Takao Kato and Pian Shu

Peer Effects, Social Networks, and Intergroup

Competition in the Workplace

ISBN 9788778823984 (print); ISBN 9788778823991 (online)

WP 09-13 Sanne Hiller and Erdal Yalcin: Switching between Domestic Market Activity, Export and FDI

ISBN 9788778824004 (print); ISBN 9788778824028 (online)

WP 09-14 Tor Eriksson and Mariola Pytlikova: Foreign Ownership Wage Premia in Emerging Economies: Evidence from Czech Republic ISBN 9788778824035 (print); ISBN 9788778824042 (online)

WP 09-15 Astrid Würtz Rasmussen: Family Structure Changes and Children's Health, Behavior, and Educational Outcomes ISBN 9788778824059 (print); ISBN 9788778824066 (online)

WP 09-16 Tor Eriksson: How Many Danish Jobs Can (Potentially) Be Done Elsewhere?

ISBN 9788778824073 (print); ISBN 9788778824080 (online)

WP 09-17 Lorenzo Cappellari, Claudio Lucifora and Dario Pozzoli: Determinants of Grades in Maths for Students in Economics ISBN 9788778824103 (print); ISBN 9788778824110 (online)

WP 09-18 Yingqiang Zhang and Tor Eriksson: Inequality of Opportunity and Income Inequality in Nine Chinese Provinces, 1989-2006 ISBN 9788778824127 (print); ISBN 9788778824134 (online) 
WP 09-19 Ricard Gil and Frederic Warzynski: Vertical Integration, Exclusivity and Game Sales Performance in the U.S. Video Game Industry ISBN 9788778824141 (print); ISBN 9788778824165 (online)

WP 09-20 Christian Gormsen: Intransparent Markets and Intra-Industry Trade ISBN 9788778824172 (print); ISBN 9788778824189 (online)

WP 09-21 Jan Bentzen and Valdemar Smith: Wine production in Denmark Do the characteristics of the vineyards affect the chances for awards?

ISBN 9788778824196 (print); ISBN 9788778824202 (online)

WP 09-22 Astrid Würtz Rasmussen: Allocation of Parental Time and the Long-Term Effect on Children's Education ISBN 9788778824233 (print); ISBN 9788778824240 (online)

2010:

WP 10-01 Marianne Simonsen, Lars Skipper and Niels Skipper:

Price Sensitivity of Demand for Prescription Drugs: Exploiting a Regression Kink Design ISBN 9788778824257 (print); ISBN 9788778824264 (online)

WP 10-02 Olivier Gergaud, Valérie Smeets and Frédéric Warzynski: Stars War in French Gastronomy: Prestige of Restaurants and Chefs'Careers ISBN 9788778824271 (print); ISBN 9788778824288 (online)

WP 10-03 Nabanita Datta Gupta, Mette Deding and Mette Lausten: Medium-term consequences of low birth weight on health and behavioral deficits - is there a catch-up effect? ISBN 9788778824301 (print); ISBN 9788778824318 (online)

WP 10-04 Jørgen Drud Hansen, Hassan Molana, Catia Montagna and Jørgen Ulff-Møller Nielsen: Work Hours, Social Value of Leisure and Globalisation ISBN 9788778824332 (print); ISBN 9788778824349 (online)

WP 10-05 Miriam Wüst: The effect of cigarette and alcohol consumption on birth outcomes ISBN 9788778824455 (print); ISBN 9788778824479 (online) 
WP 10-06 Elke J. Jahn and Michael Rosholm:Looking Beyond the Bridge: How Temporary Agency Employ-ment Affects Labor Market Outcomes ISBN 9788778824486 (print); ISBN 9788778824493 (online)

WP 10-07 Sanne Hiller and Robinson Kruse: Milestones of European Integration: Which matters most for Export Openness? ISBN 9788778824509 (print); ISBN 9788778824516 (online)

WP 10-08 Tor Eriksson and Marie Claire Villeval: Respect as an Incentive ISBN 9788778824523 (print); ISBN 9788778824530 (online)

WP 10-09 Jan Bentzen and Valdemar Smith: Alcohol consumption and liver cirrhosis mortality: New evidence from a panel data analysis for sixteen European countries ISBN 9788778824547 (print); ISBN 9788778824554 (online)

WP 10-10 Ramana Nanda: Entrepreneurship and the Discipline of External Finance ISBN 9788778824561 (print); ISBN 9788778824578 (online)

WP 10-11 Roger Bandick, Holger Görg and Patrik Karpaty: Foreign acquisitions, domestic multinationals, and R\&D ISBN 9788778824585 (print); ISBN 9788778824592 (online)

WP 10-12 Pierpaolo Parrotta, Dario Pozzoli and Mariola Pytlikova: Does Labor Diversity Affect Firm Productivity? ISBN 9788778824608 (print); ISBN 9788778824615 (online)

WP 10-13 Valérie Smeets and Frédéric Warzynski: Learning by Exporting, Importing or Both? Estimating productivity with multi-product firms, pricing heterogeneity and the role of international trade ISBN 9788778824622 (print); ISBN 9788778824646 (online)

WP 10-14 Tor Eriksson and Yingqiang Zhang: The Role of Family Background for Earnings in Rural China ISBN 9788778824653 (print); ISBN 9788778824660 (online)

WP 10-15 Pierpaolo Parrotta, Dario Pozzoli and Mariola Pytlikova: The Nexus between Labor Diversity and Firm's Innovation ISBN 9788778824875 (print); ISBN 9788778824882 (online) 
WP 10-16 Tor Eriksson and Nicolai Kristensen: Wages or Fringes?

Some Evidence on Trade-offs and Sorting

ISBN 9788778824899 (print); ISBN 9788778824905 (online)

WP 10-17 Gustaf Bruze: Male and Female Marriage Returns to Schooling ISBN 9788778824912 (print); ISBN 9788778824929 (online)

WP 10-18 Gustaf Bruze: New Evidence on the Causes of Educational Homogamy

ISBN 9788778824950 (print); ISBN 9788778824967 (online)

WP 10-19 Sarah Polborn: The Political Economy of Carbon Securities and Environmental Policy

ISBN 9788778824974 (print); ISBN 9788778824936 (online)

WP 10-20 Christian Bjørnskov and Philipp J.H. Schröder: Are Debt

Repayment Incentives Undermined by Foreign Aid?

ISBN 9788778825148 (print); ISBN 9788778825155 (online) 